\title{
Synthesis, Antibacterial, Antioxidant Activity and QSAR Studies of Novel 2-Arylidenehydrazinyl-4-arylthiazole Analogues
}

\author{
Mohammad Sayed Alam, ${ }^{a}$ Junaid Uddin Ahmed, ${ }^{b}$ and Dong-Ung Lee, \\ ${ }^{a}$ Division of Bioscience, Dongguk University; Gyeongju 780-714, Republic of Korea: and ${ }^{b}$ Department of Chemistry, \\ Jagannath University; Dhaka 1100, Bangladesh. \\ Received August 28, 2014; accepted September 28, 2014
}

A novel series of 2-arylidenehydrazinyl-4-arylthiazole analogues (3a-p) was designed and synthesized in excellent yields using a rapid, simple, efficient methodology. Sixteen novel compounds were screened for in vitro antimicrobial activities against eleven bacteria, namely, Staphylococcus aureus, Listeria monocytogenes, Enterococcus faecalis, Bacillus subtilis, Klebsiella pneumonia, Citrobacter freundii, Cronobacter sakazakii, Salmonella enteritidis, Escherichia coli, Yersinia pestis, and Pseudomonas aeruginosa. All 16 compounds showed significant anti-bacterial activities against both Gram-positive and Gram-negative bacteria. In particular, compound $3 \mathrm{~g}$ showed potent inhibition of $E$. coli and $K$. pneumonia, compound $3 \mathrm{i}$ inhibited $E$. faecalis, compound 3n S. tythi and E. faecalis, and compound 3c E. coli and $C$. sakazakii. In fact, our results indicate that most of the compounds synthesized exhibit strong antibacterial activity. The qualitative structureantibacterial activity relationships (QSAR) were studied using the physicochemical and quantum-chemical parameters of the ab initio Hartree-Fock model at the RHF/6-31G level of theory. A good qualitative correlation between predicted physicochemical parameters $(\log P$ and polar surface area (PSA)) and antibacterial activity has been found. The synthesized compounds were also evaluated for antioxidant activity. Compounds $3 \mathrm{j}$, 3a and $3 \mathrm{i}$ exhibited the greatest antioxidant activity, with $\mathrm{IC}_{50}$ values of $0.66,0.81$, and $1.08 \mu \mathrm{M}$, respectively, which were comparable to that of ascorbic acid $\left(\mathrm{IC}_{50} 0.87 \mu \mathrm{M}\right)$. The promising antibacterial and antioxidant activities of some of these synthesized 2 -arylidenehydrazinyl-4-arylthiazole derivatives, together with the results of quantum-chemical studies, could be helpful for the development of drugs to combat diseases caused by microorganisms and oxidative stress.

Key words 2-arylidenehydrazinyl-4-arylthiazole; antibacterial; antioxidant; qualitative structure-activity relationship (QSAR)

Due to the increasing number of multi-drug resistant microbial pathogens, especially Gram-positive bacteria, the treatment of infectious disease has become a challenging problem in the hospital and community. ${ }^{1)}$ Accordingly, considerable efforts are being made to identify antimicrobial agents that are effective against pathogenic microorganisms resistant to current treatments. In addition, the treatment of immune deficient individuals, such as, those infected with human immunodeficiency virus (HIV) is becoming increasingly more difficult. ${ }^{2-4)}$ Furthermore, oxidative stress produces free radicals, which are highly reactive compounds that cause serious diseases, such as, Alzheimer's disease (AD), inflammatory conditions, metabolic disorders, cellular aging, reperfusion damage, and cancer. Anti-oxidant agents are used to prevent the formation of or neutralize free radicals and repair the cell damage caused. ${ }^{5)}$ Therefore, it is important to find new classes of antibiotics with broad spectrum activity and different modes of action to combat drug resistant pathogens.

Thiazoles and their analogues have attracted continuing interest during the last few decades because of their wide range biological activities. The thiazole scaffold is an interesting component in a variety of natural and synthetic bioactive compounds used in pharmaceuticals and agrochemicals. A literature survey revealed that the synthesis of thiazole analogues has received research attention for many years due to their wide ranging pharmacological and biological properties, which include antitumor, ${ }^{6)}$ anti-inflammatory, ${ }^{7)}$ antimicrobial, ${ }^{8,9)}$ antioxidant, ${ }^{10)}$ neuroprotective, ${ }^{11)}$ antidiabetic, ${ }^{12)}$ and

The authors declare no conflict of interest antihypertensive effects. ${ }^{13)}$ Recently, it was reported that some new triazolyl-thiazole analogues showed anti-AD activity, ${ }^{14)}$ monoamine oxidase (MAO) inhibitory activity of 2-thiazolylhydrazone derivatives ${ }^{15)}$ and selective acetyl-Co-A carboxylase inhibitory activity of phenoxy thiazole derivatives. ${ }^{16)}$ More recently, Netalkar et al. ${ }^{17)}$ reported that some novel transition metal complexes of benzothiazoles showed DNA binding and cleavage properties and anti-tuberculosis activity, and TuranZitouni et al. ${ }^{18)}$ reported some new (3,4-diaryl-3H-thiazol-2ylidene)pyrimidin-2-yl amine derivatives had anti-HIV activity and selective human MAO-B inhibitory activity of novel 1-(4-arylthiazol-2-yl)-2-(3-methylcyclohexylidene)hydrazine derivatives. ${ }^{19)}$

In our previous study, ${ }^{20)}$ we observed that 2-arylidenehydrazinyl-4-arylthiazoles possessing bromine and methoxy group at the 4-position of benzylidine phenyl ring showed significant antibacterial activity. Therefore, in the present study, we designed and synthesized a series of novel 2-arylidenehydrazinyl-4-arylthiazole analogues bearing different substituents, e.g. $\mathrm{OH}, \mathrm{OMe}$, and halogen atoms in various position of phenyl ring and evaluated them as antibacterial and antioxidant agents. In vitro antibacterial activities were screened against eleven bacterial strains, that is, four Grampositive bacteria, Staphylococcus aureus (JMC 2151), Listeria monocytogenes (ATCC 43256), Enterococcus faecalis (CARS 2011-012), and Bacillus subtilis (IFO 13719) and seven Gramnegative bacteria, Klebsiella pneumonia (JCM 1662), Citrobacter freundii (JCM 1657), Cronobacter sakazakii (CARS 2012-J-F), Salmonella enteritidis (ATC C 13076), Escherichia coli (CARS 2011-016), Yersinia pestis (CARS 2013-027), and 
Pseudomonas aeruginosa (PA01). The qualitative structureantibacterial activity relationships (QSAR) were studied using physicochemical and quantum-chemical parameters with the ab initio Hartree-Fock model at the RHF/6-31G level of theory using GAMESS interface in the ChemBio3D Pro 12 and molinspiration cheminformatics software. The 1,1-diphenyl2-picrylhydrazyl (DPPH) free radical scavenging activities of synthesized compounds were investigated to determine their antioxidant properties.

\section{Results and Discussion}

Synthesis The synthesis of the 2-arylidenehydrazinyl4-arylthiazoles $(\mathbf{3 a}-\mathbf{p})$ analogues was carried as we previously reported using the Hantzsch method ${ }^{21)}$ from their corresponding arylidenethiosemicarbazones. The synthetic routes to arylidenethiosemicarbazones (2a-j) and 2-arylidenehydrazinyl4-arylthiazoles $(\mathbf{3 a}-\mathbf{p})$ are outlined in Chart 1. Compounds $\mathbf{2 a}-\mathbf{j}$ were prepared by the condensation of thiosemicarbazide and a substituted benzaldehyde in ethanol in excellent yield (83-94\%) and their structures were determined using IR, ${ }^{1} \mathrm{H}-\mathrm{NMR}$, and mass spectral data. The syntheses of compounds $\mathbf{2} \mathbf{g}-\mathbf{j}$ were reported in our previous study. ${ }^{20)}$ The IR spectra of the newly synthesized compounds $\mathbf{2 a - f}$ showed an absorption band around the $3437-3405 \mathrm{~cm}^{-1}$ region resulting from the $-\mathrm{OH}$ and $-\mathrm{NH}_{2}$ groups. The stretching absorption band of $-\mathrm{NH}-$ appeared at $3270-3241 \mathrm{~cm}^{-1}$. ${ }^{1} \mathrm{H}-\mathrm{NMR}$ spectra of compounds $\mathbf{2 a}-\mathbf{f}$ showed singlet protons at $8.08-8.24 \mathrm{ppm}$ corresponding to the $-\mathrm{CH}=\mathrm{N}-$ proton and at $11.18-11.40 \mathrm{ppm}$ for the $=\mathrm{N}-\mathrm{NH}-$ proton. In addition, two amino $\left(-\mathrm{NH}_{2}\right)$ protons appeared as two singlets at 7.76-7.96 and 7.93-8.02 ppm due to en-thiol tautomerism, which were not observed for compounds 3a-p. The electron ionization-mass spectrometry

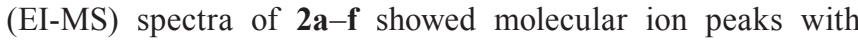
intensities of $95-100 \%$.

Hantzsch thioazole synthesis ${ }^{21)}$ applied to arylidenethiosemicarbazones $(\mathbf{2} \mathbf{a}-\mathbf{j})$ and 2-bromoacetophenone or 2,4'-dibromoacetophenone gave the novel 2-arylidenehydrazinyl- 4-arylthiazoles $(\mathbf{3 a}-\mathbf{p})$ in good yield $(72-95 \%)$. The structures of compounds $\mathbf{3} \mathbf{a}-\mathbf{p}$ were elucidated by IR, ${ }^{1} \mathrm{H}-\mathrm{NMR}$, and MS. In the IR spectra of compounds $\mathbf{3 a}-\mathbf{p}$, the characteristic $\mathrm{O}-\mathrm{H}$ and $\mathrm{N}-\mathrm{H}$ stretching absorption bands appeared at $3400-3475 \mathrm{~cm}^{-1}$ and $3150-3275 \mathrm{~cm}^{-1}$, respectively. The ${ }^{1} \mathrm{H}-\mathrm{NMR}$ spectra of compounds $\mathbf{3} \mathbf{a}-\mathbf{p}$ revealed the presence of the $-\mathrm{CH}=\mathrm{N}-$ proton and the $=\mathrm{N}-\mathrm{NH}-$ proton as two singlets at $7.93-8.49$ and $11.11-12.23 \mathrm{ppm}$, respectively. The thiazole proton appeared as a multiplet at 7.00-7.81 ppm together with phenyl protons. In addition, the EI-MS or FAB-MS spectra of $3 \mathbf{a}-\mathbf{p}$ showed molecular ion peaks with intensities of $5-87 \%$.

Antibacterial Activity The newly synthesized 2-arylidenehydrazinyl-4-arylthiazoles $(\mathbf{3 a}-\mathbf{p})$ were evaluated for their in vitro antibacterial activities against four Gram-positive bacteria and seven Gram-negative bacteria (as detailed above) using disc diffusion methods. As presented in Table 1, all tested compounds remarkably resisted the growth of Grampositive and Gram-negative bacteria at a dose of $300 \mu \mathrm{gdisc}^{-1}$, and showed activities at this loading comparable to nalidixic acid (positive control) at $50 \mu \mathrm{gdisc}^{-1}$. It is worth noting that all compounds showed bactericidal activity against L. monocytogenes, B. subtilis (except $\mathbf{3 g}$ and $\mathbf{3 p}$ ), C. sakazakii, and E. coli. In addition, many of the compounds also showed antibacterial activity against $S$. aureus, E. faecalis, Y. pestis and $P$. aeruginosa. Five (3f, $\mathbf{3 g}, \mathbf{3 j}, \mathbf{3} \mathbf{l}$, and $\mathbf{3 m})$ and eight $(\mathbf{3 a}, \mathbf{3 b}$, 3e, 3f, 3h, 3i, 3l, and 3n) compounds showed activity against $K$. pneumonia and $S$. enteritidis, respectively. None of the compounds inhibited the growth of $C$. frenudii at a concentration of $300 \mu \mathrm{g} \mathrm{disc}^{-1}$. In detail, compound $\mathbf{3 g}$ showed strong and greatest activity against $E$. coli and $K$. pneumonia, and produced an inhibition zone similar to that of nalidixic acid. Compounds $\mathbf{3 i}$ and $\mathbf{3 n}$ also strongly inhibited the growth of E. faecalis and S. enteritidis, respectively, and showed larger inhibition zones than nalidixic acid. Compound 3c showed moderate activity against $C$. sakazakii and E. coli, while compound $\mathbf{3 b}$ also exhibited moderate activity against $C$. sakazakii and E. faecalis. Compounds $\mathbf{3 e}$ and $\mathbf{3 m}$ also demonstrated

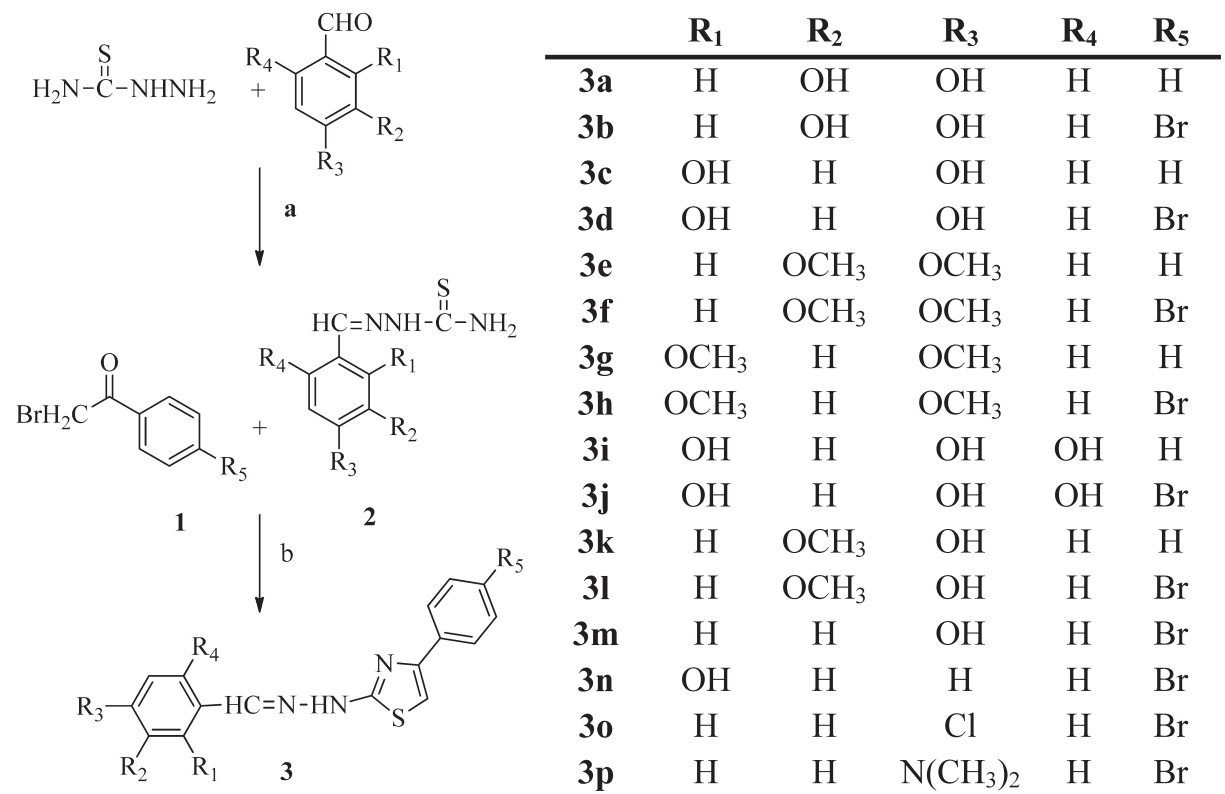

Reagents and conditions: (a) EtOH- $\mathrm{H}_{2} \mathrm{O}$, reflux, yield 83-94\%; (b) EtOH, reflux, yield 72-95\%.

Chart 1. Synthesis of the Novel 2-Arylidenehydrazinyl-4-arylthiazole Analogues 3a-p 
moderate activity against E. faecalis. All compounds, 3a-p $\left(300 \mu \mathrm{g} \mathrm{disc}^{-1}\right)$ showed better activity against L. monocytogenes than nalidixic acid $\left(50 \mu \mathrm{gdisc}^{-1}\right)$. Compounds $\mathbf{3 a}, \mathbf{3 b}$, 3e, 3f, 3h, 3i, and 3l-n showed good activity against $Y$. pestis, whereas nalidixic acid showed no activity at $50 \mu \mathrm{gdisc}^{-1}$. The minimal inhibitory concentrations (MICs) of most active compounds were determined against some selected bacterial strains and the results are summarized in Table 2.

Structure-antimicrobial activity relationships did not appear to play a significant role as all compounds, with some exceptions (e.g., E. coli), exhibited similar bactericidal effects. This result led us to speculate that the mode of action of these compounds is microorganism dependent. However, the presence of an electron donating group $(\mathrm{OMe})$ at the $\mathrm{R}_{1}$ and $\mathrm{R}_{3}$ posi- tions favored activity (3g), while the presence of a more polar group $(\mathrm{OH})$ at the same positions reduced activity $(\mathbf{3 c})$ against E. coli. Introduction of a bromine atom (an electron donating group) at $\mathrm{R}_{5}$ position greatly reduced antibacterial efficacy (e.g., $\mathbf{3 g}>\mathbf{3 h}$ and $\mathbf{3} \mathbf{c}>\mathbf{3 d}$ ). In most compounds substituent types and positions did not unduly affect antibacterial activity.

Computational Studies The electronic properties e.g. frontier molecular orbitals (FMOs) and physicochemical properties e.g. lipophilicity play an important role in exerting molecular reactivity in biological response. To explain the qualitative structure-antibacterial activity relationships (QSAR) of 2-arylidenehydrazinyl-4-arylthiazole (3a-p), quantum-chemical and physicochemical calculations were carried out with $a b$ initio Hartree-Fock model at the $6-31 \mathrm{G}$ basis set using

Table 1. In Vitro Bactericidal Profiles of the Novel 2-Arylidenehydrazinyl-4-arylthiazole Analogues 3a-p in Terms of Zone of Inhibition

\begin{tabular}{|c|c|c|c|c|c|c|c|c|c|c|c|}
\hline \multirow{2}{*}{ Compd. } & \multicolumn{5}{|c|}{ Gram-positive } & \multicolumn{6}{|c|}{ Gram-negative } \\
\hline & S. $a$. & L. $m$. & E. $f$. & B. s. & K. $p$. & C. $f$. & C. $s$. & S. e. & E. c. & Y. $p$. & P. $a$. \\
\hline $3 a$ & $10 \pm 1.0$ & $13 \pm 0.5$ & $12 \pm 1.0$ & $12 \pm 1.0$ & - & - & $14 \pm 1.0$ & $10 \pm 1.0$ & $13 \pm 1.0$ & $10 \pm 1.0$ & $12 \pm 1.0$ \\
\hline $3 b$ & $10 \pm 1.0$ & $12 \pm 0.5$ & $12 \pm 0.5$ & $12 \pm 1.0$ & - & - & $15 \pm 0.5$ & $11 \pm 1.0$ & $14 \pm 0.5$ & $10 \pm 1.0$ & $11 \pm 1.0$ \\
\hline $3 c$ & - & $13 \pm 1.0$ & - & $11 \pm 1.0$ & - & - & $15 \pm 0.5$ & - & $16 \pm 0.5$ & - & - \\
\hline 3d & - & $11 \pm 1.0$ & - & $11 \pm 1.0$ & - & - & $11 \pm 1.0$ & - & $11 \pm 1.0$ & - & - \\
\hline $3 e$ & $10 \pm 1.0$ & $12 \pm 0.5$ & $15 \pm 0.5$ & $11 \pm 1.0$ & - & - & $13 \pm 1.0$ & $12 \pm 1.0$ & $13 \pm 1.0$ & $10 \pm 1.0$ & $11 \pm 1.0$ \\
\hline $3 f$ & $11 \pm 0.5$ & $13 \pm 0.5$ & $13 \pm 1.0$ & $11 \pm 1.0$ & $10 \pm 1.0$ & - & $14 \pm 1.0$ & $12 \pm 1.0$ & $14 \pm 0.5$ & $10 \pm 1.0$ & $12 \pm 1.0$ \\
\hline $3 g$ & - & $11 \pm 1.0$ & - & - & $17 \pm 1.0$ & - & $12 \pm 1.0$ & - & $22 \pm 1.0$ & - & - \\
\hline $3 \mathrm{~h}$ & $11 \pm 1.0$ & $13 \pm 1.0$ & $12 \pm 1.0$ & $12 \pm 1.0$ & - & - & $12 \pm 1.0$ & $12 \pm 1.0$ & $14 \pm 1.0$ & $13 \pm 0.5$ & $10 \pm 0.5$ \\
\hline $3 \mathbf{i}$ & $11 \pm 1.0$ & $14 \pm 0.5$ & $17 \pm 0.5$ & $14 \pm 0.5$ & - & - & $13 \pm 0.5$ & $12 \pm 1.0$ & $13 \pm 1.0$ & $13 \pm 0.5$ & $13 \pm 1.0$ \\
\hline $3 \mathbf{j}$ & $12 \pm 0.5$ & $13 \pm 1.0$ & $13 \pm 1.0$ & $11 \pm 1.0$ & $10 \pm 1.0$ & - & $12 \pm 1.0$ & - & $13 \pm 1.0$ & $9 \pm 0.5$ & $12 \pm 1.0$ \\
\hline $3 \mathrm{k}$ & - & $11 \pm 1.0$ & - & $10 \pm 1.0$ & - & - & $11 \pm 1.0$ & - & $11 \pm 1.0$ & - & - \\
\hline 31 & $11 \pm 1.0$ & $12 \pm 1.0$ & $11 \pm 1.0$ & $10 \pm 1.0$ & $10 \pm 0.5$ & - & $12 \pm 1.0$ & $10 \pm 1.0$ & $13 \pm 1.0$ & $10 \pm 1.0$ & $12 \pm 1.0$ \\
\hline $3 m$ & $11 \pm 1.0$ & $12 \pm 0.5$ & $15 \pm 1.0$ & $11 \pm 1.0$ & $11 \pm 1.0$ & - & $13 \pm 1.0$ & - & $12 \pm 1.0$ & $11 \pm 1.0$ & $11 \pm 1.0$ \\
\hline $3 n$ & $12 \pm 1.0$ & $11 \pm 1.0$ & $15 \pm 1.0$ & $10 \pm 1.0$ & - & - & $11 \pm 1.0$ & $16 \pm 0.5$ & $12 \pm 1.0$ & $13 \pm 1.0$ & $11 \pm 1.0$ \\
\hline 30 & - & $11 \pm 1.0$ & - & $10 \pm 1.0$ & - & - & $12 \pm 1.0$ & - & $11 \pm 1.0$ & - & $10 \pm 1.0$ \\
\hline $3 p$ & - & $11 \pm 1.0$ & - & - & - & - & $12 \pm 0.5$ & - & $11 \pm 1.0$ & - & - \\
\hline NA & $25 \pm 1.0$ & $9 \pm 0.5$ & $15 \pm 1.0$ & $22 \pm 1.0$ & $20 \pm 1.0$ & $17 \pm 1.0$ & $23 \pm 1.0$ & $14 \pm 1.0$ & $23 \pm 1.0$ & - & $20 \pm 1.0$ \\
\hline
\end{tabular}

Inhibitory activities are expressed as observed inhibition zone diameters (in mm). (-), No activity. Results are the means \pm S.D. of at least three experiments. S. a., Staphylococcus aureus (JMC 2151); L. m., Listeria monocytogenes (ATCC 43256); E. f., Enterococcus faecalis (CARS 2011-012); B. s., Bacillus subtilis (IFO 13719); K. p., Klebsiella pneumonia (JCM 1662); C. f., Citrobacter freundii (JCM 1657); C. s., Cronobacter sakazakii (CARS 2012-J-F); S. e., Salmonella enteritidis (ATCC 13076); E. c., E. coli (CARS 2011-016); Y. p., Yersinia pestis (CARS 2013-027); P.a., Pseudomonas aeruginosa (PA01). Compounds were loaded at $300 \mu \mathrm{g}$ disc ${ }^{-1}$, and the positive control (nalidixic acid (NA)) was loaded at $50 \mu \mathrm{g} \mathrm{disc}^{-1}$.

Table 2. MICs of the Novel 2-Arylidenehydrazinyl-4-arylthiazole Analogues 3a-p against Selected Bacterial Strains

\begin{tabular}{|c|c|c|c|c|c|c|c|c|}
\hline \multirow{3}{*}{ Compd. } & \multicolumn{8}{|c|}{ Minimum inhibitory concentration (MIC), $\mu \mathrm{g} \mathrm{mL}^{-1}$} \\
\hline & \multicolumn{4}{|c|}{ Gram-positive } & \multicolumn{4}{|c|}{ Gram-negative } \\
\hline & L. $m$. & E. $f$. & B. $s$. & K. $p$. & C. $s$. & S. e. & E. c. & $Y . p$. \\
\hline $3 \mathbf{b}$ & 150 & - & - & - & 100 & - & - & - \\
\hline $3 c$ & 50 & - & - & - & 100 & & 200 & - \\
\hline $3 e$ & 150 & 100 & - & - & - & & - & - \\
\hline $3 f$ & 100 & - & - & - & - & & - & - \\
\hline $3 g$ & 200 & - & - & 50 & - & & 50 & - \\
\hline $3 h$ & 100 & - & - & - & - & & - & 50 \\
\hline $3 \mathbf{i}$ & 50 & 50 & 150 & - & - & & - & 50 \\
\hline $3 \mathbf{j}$ & 50 & - & - & - & - & & - & - \\
\hline $3 m$ & 100 & 50 & - & - & - & & - & - \\
\hline $3 n$ & 150 & 100 & - & - & - & 50 & - & 75 \\
\hline NA & 25 & 25 & 12 & 12 & 12 & 12 & 12 & - \\
\hline
\end{tabular}

(一), Not measured. NA, nalidixic acid. L. m., Listeria monocytogenes (ATCC 43256); E. f., Enterococcus faecalis (CARS 2011-012); B. s., Bacillus subtilis (IFO 13719); K. p., Klebsilla pneumonia (JCM 1662); C. s., Cronobacter sakazakii (CARS 2012-J-F); S. t., Salmonella enteritidis (ATCC 13076); E. c., E. coli (CARS 2011-016); Y. p., Yersinia pestis (CARS 2013-027). 
ChemBio3D Pro 12 molecular modeling and molinspiration cheminformatics software, respectively. Quantum-chemical properties of some selected highly active (3c, $\mathbf{3 g}, \mathbf{3 i}$, and $\mathbf{3 n}$ ) and low active (3d and $\mathbf{3 k}$ ) compounds are presented in Table 3. The calculated Hartree-Fock total energy of compounds $\mathbf{3 c}, \mathbf{3 g}, \mathbf{3 i}$, and $\mathbf{3 n}$ are lower than that of $\mathbf{3 d}$ and $\mathbf{3 k}$, indicating that the highly active compounds are more thermodynamically stable. Moreover, the energy differences between highest occupied molecular orbital (HOMO) and lowest unoccupied molecular orbital (LUMO) of $\mathbf{3 c}(6.447 \mathrm{eV}), \mathbf{3 g}(6.577 \mathrm{eV}), \mathbf{3 i}$ $(6.247 \mathrm{eV})$, and $\mathbf{3 n}(6.752 \mathrm{eV})$ are less than that of $\mathbf{3 d}(7.022 \mathrm{eV})$ and $3 \mathbf{k}(6.808 \mathrm{eV})$. It was reported that thiazole peptide class of antibiotics exerts their bactericidal action using sulfur atom of thiazole ring and amine group to bind to the target site which causes cell lysis and membrane disruption as well as bacterial protein biosynthesis inhibition. Figure 1 shows

Table 3. Quantum-chemical Properties of Selected Highly Active (3c, 3g, 3n, and 3i) and Low Active (3d and 3k) 2-Arylidenehydrazinyl-4-arylthiazole Analogues

\begin{tabular}{|c|c|c|c|c|c|c|}
\hline Compd. & $E_{\mathrm{HF}}(\mathrm{kJ} / \mathrm{mol})$ & $E_{\text {Номо }}(\mathrm{eV})$ & $E_{\text {LUMO }}(\mathrm{eV})$ & $\Delta E_{\text {номо-Luмо }}(\mathrm{eV})$ & $H_{\mathrm{F}}(\mathrm{kcal} / \mathrm{mol})$ & Dipole (Db) \\
\hline $3 c$ & -3456703.9 & -6.768 & -0.321 & 6.447 & 341.10 & 3.21 \\
\hline 3d & -1017662.3 & -6.643 & 0.379 & 7.022 & 235.72 & 4.63 \\
\hline $3 g$ & -3660418.9 & -6.938 & -0.361 & 6.577 & 250.57 & 3.92 \\
\hline $3 \mathbf{i}$ & -3652160.1 & -6.483 & -0.236 & 6.247 & 299.06 & 4.82 \\
\hline $3 \mathrm{k}$ & -2558174.6 & -7.026 & -0.218 & 6.808 & 351.96 & 2.73 \\
\hline $3 n$ & -3981173.8 & -6.908 & -0.156 & 6.752 & 391.86 & 4.84 \\
\hline
\end{tabular}

$E_{\mathrm{HF}}$-Total energy; $E_{\mathrm{LUMO}}-$ Energy of lowest unoccupied molecular orbital; $E_{\mathrm{HOMO}}$-Energy of Highest occupied molecular orbital; $\Delta E_{\mathrm{HOMO}-\mathrm{LuMO}}-$ Energy difference between HOMO and LUMO; $H_{\mathrm{F}}-$ Heat of formation.

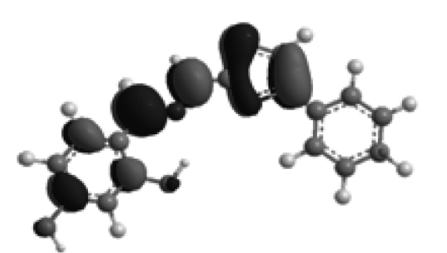

A
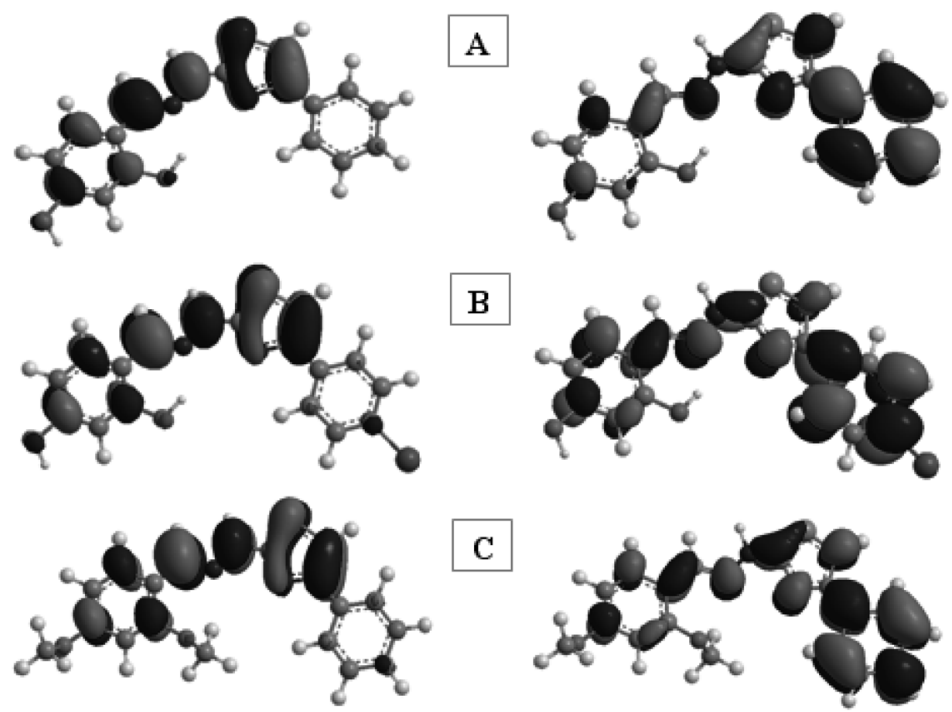

\section{B}
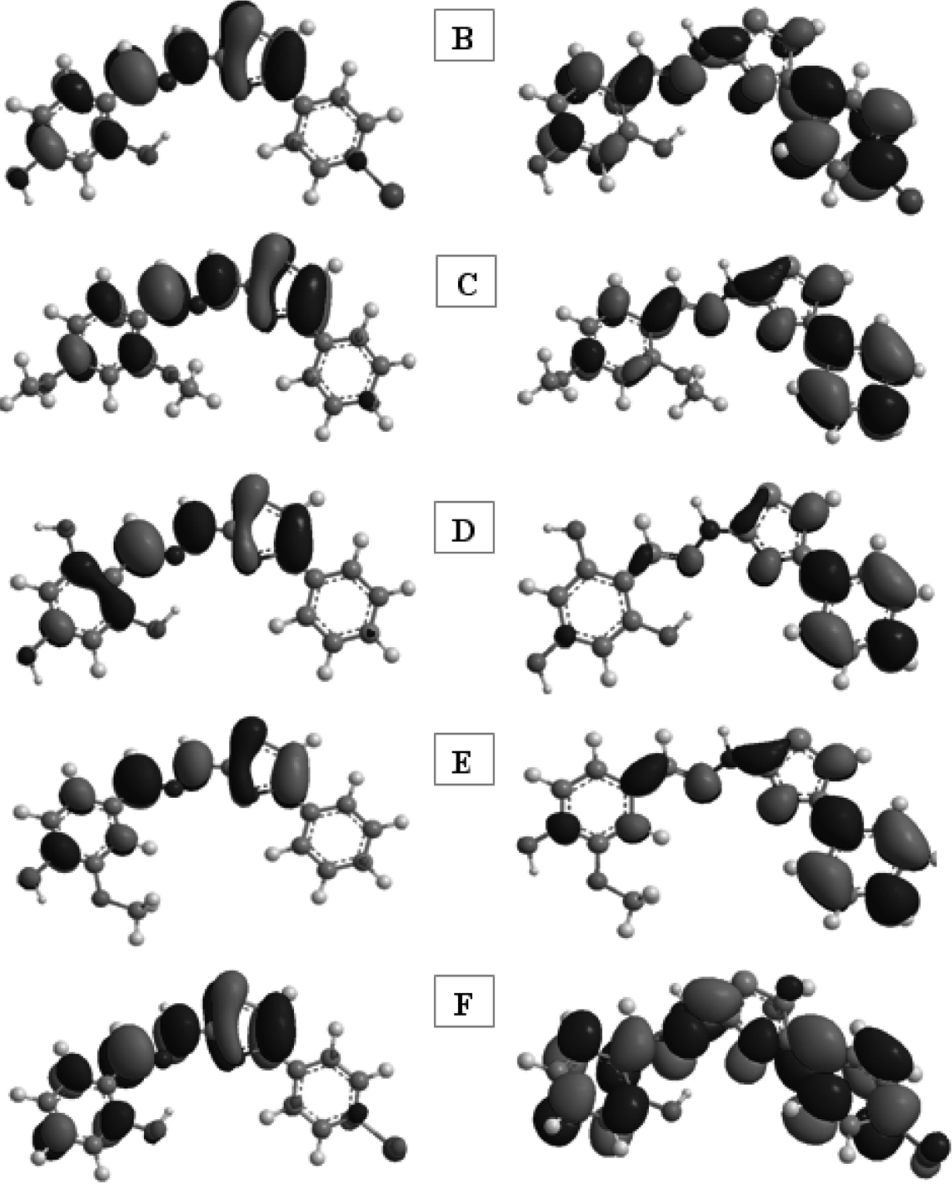

Fig. 1. HOMO and LUMO Isosurfaces for 3c (A), 3d (B), 3g (C), 3i (D), 3k (E), and 3n (F)

Different surface colors represent opposite signs of the wave function. 
Table 4. Physico-chemical Properties of the Novel 2-Arylidenehydrazinyl-4-arylthiazole Analogues 3a-p

\begin{tabular}{|c|c|c|c|c|c|c|c|}
\hline Compd. & MW (g/mol) & $\mathrm{c} \log P^{a)}$ & TPSA $^{b)}$ & $\mathrm{OH}-\mathrm{NH}$ interact ${ }^{c}$ & $\mathrm{O}-\mathrm{N}$ interact ${ }^{d)}$ & $n \operatorname{rot} b^{e)}$ & Volume \\
\hline $3 a$ & 311.366 & 3.198 & 77.739 & 3 & 5 & 4 & 265.114 \\
\hline $3 \mathbf{b}$ & 390.262 & 3.508 & 77.739 & 3 & 5 & 4 & 283.0 \\
\hline $3 c$ & 311.366 & 3.394 & 77.739 & 3 & 5 & 4 & 265.114 \\
\hline 3d & 390.262 & 4.203 & 77.739 & 3 & 5 & 4 & 283.0 \\
\hline $3 e$ & 339.42 & 3.504 & 55.751 & 1 & 5 & 6 & 300.17 \\
\hline $3 f$ & 418.316 & 4.213 & 55.751 & 1 & 5 & 6 & 318.056 \\
\hline $3 g$ & 339.42 & 3.999 & 55.751 & 1 & 5 & 6 & 300.17 \\
\hline $3 \mathrm{~h}$ & 418.316 & 4.508 & 55.751 & 1 & 5 & 6 & 318.056 \\
\hline $3 \mathbf{i}$ & 327.365 & 3.511 & 97.967 & 4 & 6 & 4 & 273.132 \\
\hline $3 \mathbf{j}$ & 406.261 & 4.355 & 97.967 & 4 & 6 & 4 & 291.018 \\
\hline $3 k$ & 325.393 & 3.296 & 66.745 & 2 & 5 & 5 & 282.642 \\
\hline 31 & 404.289 & 4.105 & 66.745 & 2 & 5 & 5 & 300.528 \\
\hline $3 m$ & 374.263 & 4.187 & 57.511 & 2 & 4 & 4 & 274.982 \\
\hline $3 n$ & 374.263 & 4.857 & 57.511 & 2 & 4 & 4 & 274.982 \\
\hline 30 & 392.709 & 5.444 & 37.283 & 1 & 3 & 4 & 280.5 \\
\hline $3 p$ & 401.333 & 4.868 & 40.521 & 1 & 4 & 5 & 312.87 \\
\hline
\end{tabular}

a) Calculated octanol-water partition coefficient; $b$ ) Molecular polar surface area; $c$ ) Number of hydrogen-bond donors; $d$ ) Number of hydrogen-bond acceptors; $e$ ) Number of rotatable bond.
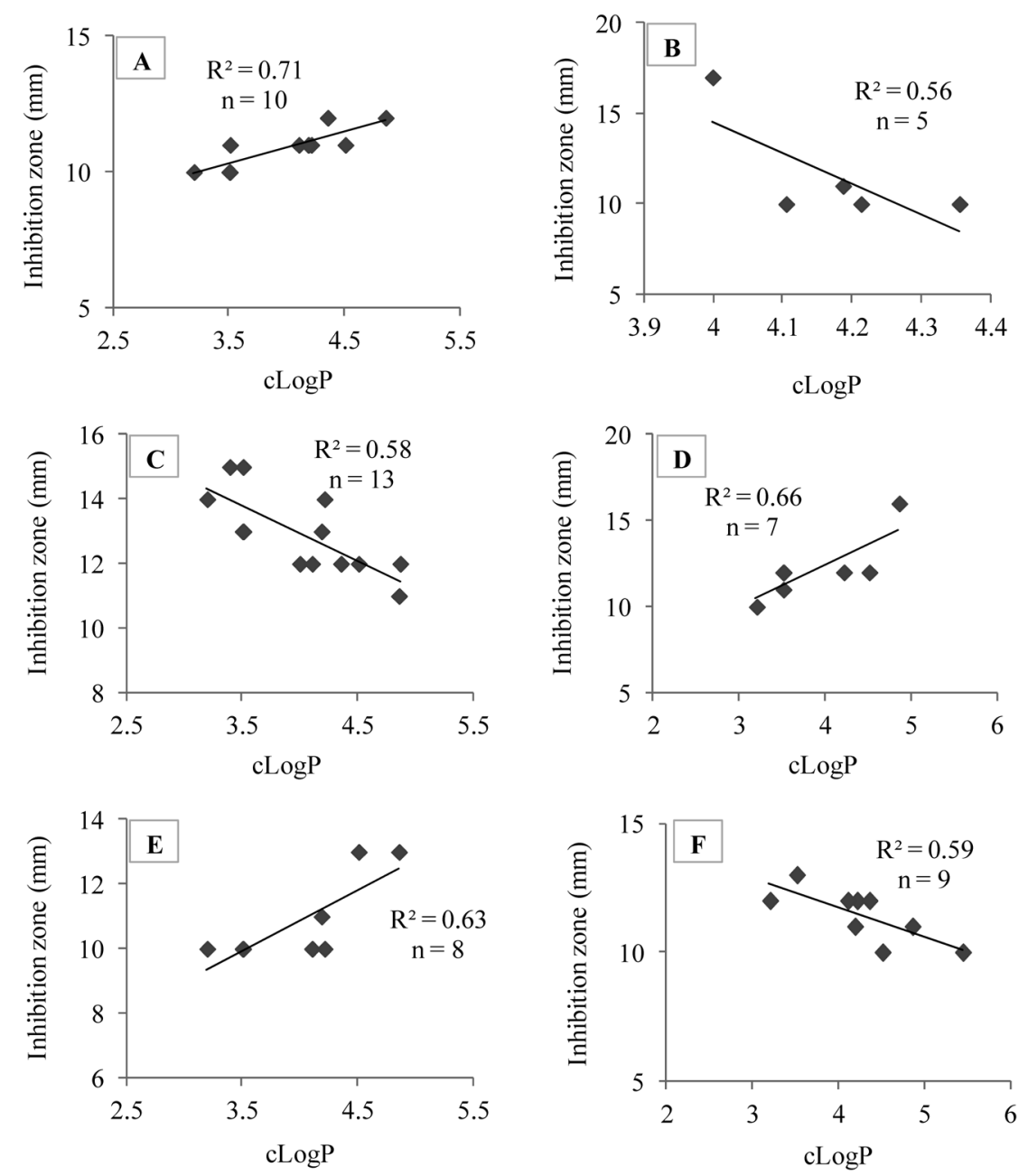

Fig. 2. Correlation between Calculated Octanol-Water Partition Coefficient (c Log $P$ ) and Inhibitory Potency in Selected 2-Arylidenehydrazinyl4-arylthiazole Analogues against: (A) Staphylococcus aureus, (B) Klebsilla pneumonia, (C) Cronobacter sakazakii, (D) Salmonella enteritidis, (E) Yersinia pestis, and (F) Pseudomonas aeruginosa 
HOMO and LUMO isosurfaces for 3c (A), 3d (B), 3g (C), 3i (D), 3k (E), and 3n (E). As we observed, electron density around the sulfur atom are less in low active compounds e.g., $\mathbf{3 d}$ and $\mathbf{3 k}$, whereas more in highly active compounds e.g., $\mathbf{3 c}$, $\mathbf{3 g}, \mathbf{3 i}$, and $\mathbf{3 n}$, indicating this region can act as a potential biological nucleophiles. The above results are consistent with our previous study. ${ }^{21)}$

Octanol-water partition coefficient $(\log P)$ of a molecule depends on two important factors, i.e. lipophilicity and polar surface area (PSA), which help the molecule to cross or irreversibly damage the cellular membrane. Therefore, $\log P$ and PSA is recognized as a meaningful parameter in structure-activity relationship studies. They are the most informative and successful physicochemical properties in medicinal chemistry $^{22,23)}$ and are used as a major experimental and theoretical tool in drug design. Physiochemical parameters of 2-arylidenehydrazinyl-4-arylthiazole analogues $(\mathbf{3 a}-\mathbf{p})$ are listed in Table 4. It is known that biological activity usually correlates with $\log P$ and PSA of a molecule. ${ }^{23,24)}$ The correlation coefficients $\left(r^{2}\right)$ between the $\operatorname{cog} P$ and inhibitory potencies of active 2-arylidenehydrazinyl-4-arylthiazole analogues against S. aureus, K. pneumonia, E. faecalis, C. sakazakii, S. enteritidis, Y. pestis, and $P$. aeruginosa were found to be $0.71(n=10$; 3a, 3b, 3e, 3f, 3h-j, and 3l-n), $0.56(n=5 ; \mathbf{3 f}, \mathbf{3 g}, \mathbf{3 j}, \mathbf{3 \mathbf { l }}$, and $\mathbf{3 m}), 0.54(n=7 ; \mathbf{3 e}, \mathbf{3 f}, \mathbf{3 h}-\mathbf{j}, \mathbf{3 l}$, and $\mathbf{3 m}), 0.58(n=13 ; \mathbf{3 a}-\mathbf{c}$, $\mathbf{3 e}-\mathbf{j}, \mathbf{3 l}-\mathbf{n}$, and $\mathbf{3 p}$ ), $0.66(n=7$; 3a, 3b, 3e, 3f, 3h, 3i , and $\mathbf{3 n})$, $0.63(n=8 ; \mathbf{3 a}, \mathbf{3 b}, \mathbf{3 e}, \mathbf{3 f}, \mathbf{3 h}$, and $\mathbf{3 \mathbf { l }}-\mathbf{n})$ and $0.59(n=9 ; \mathbf{3 a}$, $\mathbf{3 f}, \mathbf{3 h}-\mathbf{j}$, and $\mathbf{3 \mathbf { l }}-\mathbf{0})$, respectively. Although a small number of compounds were used in the present study, a significant correlation was observed in which antibacterial activity decreased with increasing $\mathrm{c} \log P$ against $K$. pneumonia, $C$. sakazakii, and $P$. aeruginosa, while activity increased with increasing c $\log P$ against $S$. aureus, $S$. enteritidis, and $Y$. pestis (Fig. 2). However, the correlation coefficients $\left(r^{2}\right)$ between PSAs and inhibitory potencies of active 2-arylidenehydrazinyl-4-arylthiazole analogues against L. monocytogenes, B. subtilis, $Y$. pestis, and $P$. aeruginosa were found to be $0.56(n=14, \mathbf{3 a}-\mathbf{c}$, $\mathbf{3 e}-\mathbf{j}$, and 3l-p), $0.57(n=12 ; \mathbf{3 a}-\mathbf{f}, \mathbf{3 i}$, and $\mathbf{3 k}-\mathbf{0}), 0.70 \quad(n=7$; $\mathbf{3 a}, \mathbf{3 b}, \mathbf{3 h}, \mathbf{3} \mathbf{j}$, and $\mathbf{3 \mathbf { l }}-\mathbf{n})$ and $0.71(n=10 ; \mathbf{3} \mathbf{a}, \mathbf{3 b}, \mathbf{3 e}, \mathbf{3 h}-\mathbf{j}$, and 3l-o), respectively. As shown in Fig. 3, a good correlation was observed in which antibacterial activity increased with increasing PSA against L. monocytogenes, B. subtilis, and $P$. aeruginosa whereas, activity increased with decreasing PSA against $Y$. pestis. Correlation trends shown in Figs. 2 and 3, indicating that the mode of action of 2-arylidenehydrazinyl4-arylthiazole analogues against $K$. pneumonia, L. monocytogenes, B. subtilis, C. sakazakii, and $P$. aeruginosa might be same, but different from $S$. aureus, $S$. enteritidis, and $Y$. pestis. As presented in Table 1, all the compounds (3a-p) showed selective bactericidal activity but did not showed activity against all bacterial strains even $\operatorname{cog} P$ and PSAs values are fallen within the range of higher to lower active compounds. Therefore, maps of lipophilicity potential (MLP) and PSA of some selected highly active (3c, 3g, 3i, and $\mathbf{3 n}$ ) and low active compounds (3d and $\mathbf{3 k}$ ) were compared with each other, indicating that the polarity and lipophilicity are different for all molecules (Fig. 4). The above result led us to speculate that the distribution of lipophilic and polar area in the molecular surface is also important to exert their biological activity together with the total lipophilicity and hydrophilicity of a molecule.

Antioxidant Activity Compounds 3a-p were evaluated for their free radical scavenging activities using DPPH. As shown in Table 5, all compounds exhibited significant DPPH radical scavenging activity. Of the compounds examined, $\mathbf{3 j}$, $\mathbf{3 a}$, and $\mathbf{3 i}$ showed greatest activity followed by $\mathbf{3 c}, \mathbf{3 l}, \mathbf{3 e}$, 3f, and $\mathbf{3 n}$. The $\mathrm{IC}_{50}$ values of compound $\mathbf{3 j}(0.66 \mu \mathrm{M})$ and 3a $(0.81 \mu \mathrm{M})$ were lower than that of the standard antioxidant
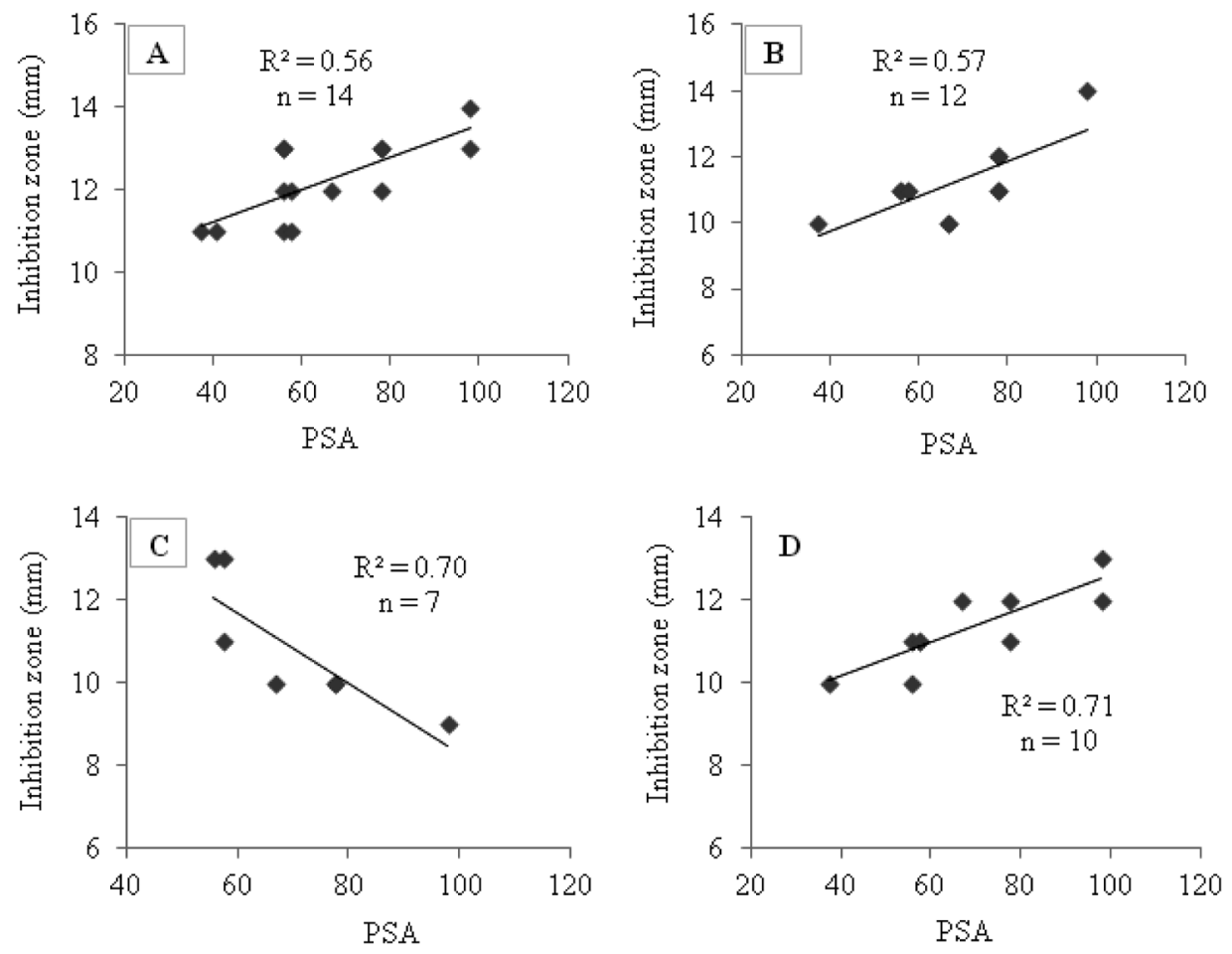

Fig. 3. Correlation between Polar Surface Area (PSA) and Inhibitory Potency in Selected 2-Arylidenehydrazinyl-4-arylthiazole Analogues against: (A) Listeria monocytogenes, (B) Bacillus subtilis, (C) Yersinia pestis, and (D) Pseudomonas aeruginosa 


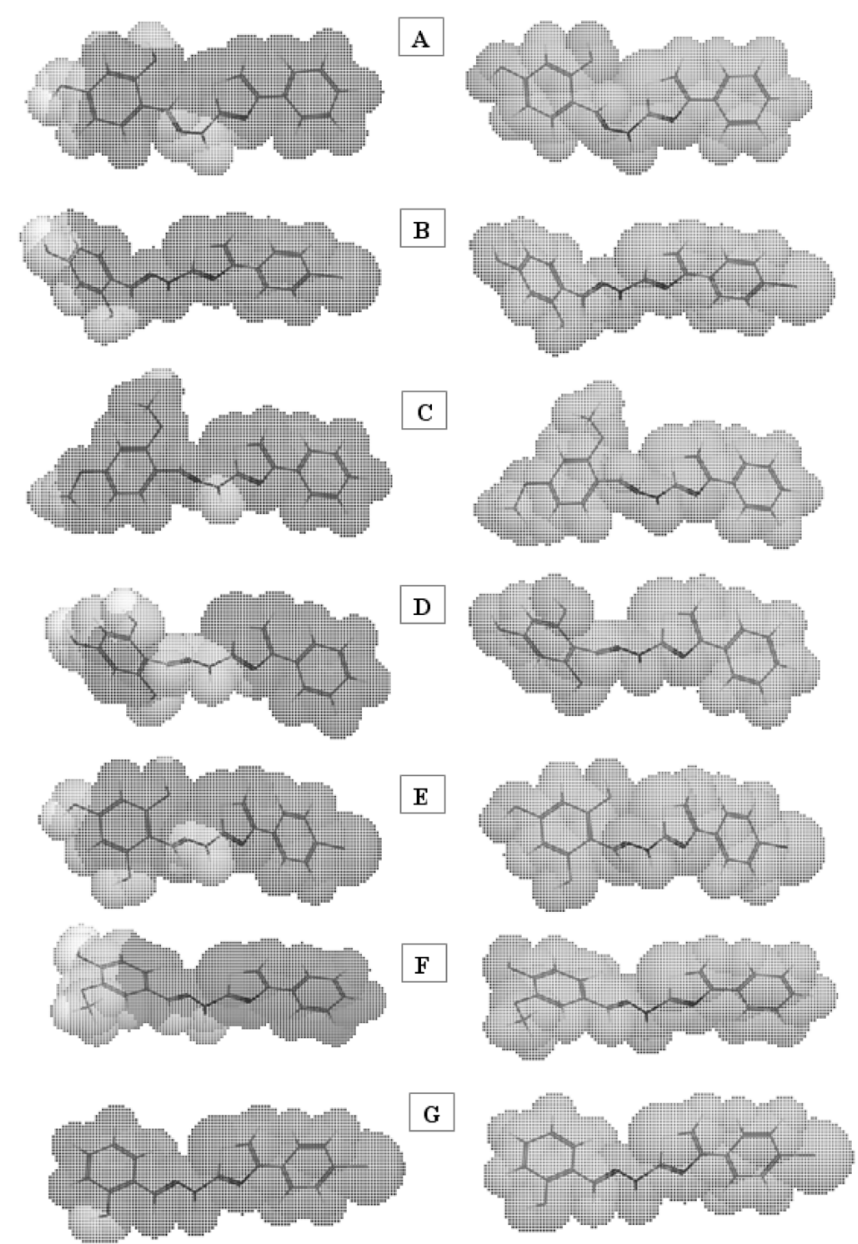

Fig. 4. Molecular Lipophilicity Potential (Left) and Polar Surface Area (Right) for 3c (A), 3d (B), 3g (C), 3i (D), 3j (E), 3k (F), and 3n (G) Showing the Most Lipophilic Area (Blue Color), Intermediate Lipophilic Area (Pink Color), Most Hydrophilic Area (Yellow Color), Intermediate Hydrophilic Area (Green Color), Nonpolar Area (Gray White Color), and Polar Area (Red Color)

(Color images were converted into gray scale.)

agent, ascorbic acid $(0.87 \mu \mathrm{M})$. Polyphenols containing more hydroxyl groups, such as, $\mathbf{3 i}$ and $\mathbf{3} \mathbf{j}$, are known to exhibit excellent antioxidant activities. Among the non-hydroxylated analogues, $\mathbf{3 e}$ and $\mathbf{3 f}$ exerted remarkable activity, whereas the activities of $\mathbf{3 g}, \mathbf{3 h}, \mathbf{3 o}$, and $\mathbf{3 p}$ were relatively weak.

Among the hydroxylated 2-arylidenehydrazinyl-4-arylthiazoles, compounds containing a bromine atom $(\mathbf{3 b}, \mathbf{3} \mathbf{d}, \mathbf{3} \mathbf{f}$, and 3h) at the $R_{5}$ position showed less antioxidant activity than their non-brominated analogues (3a, 3c, 3e, and 3g), except compounds $\mathbf{3 j}$ and $\mathbf{3 l}$. Complete $O$-methylation of compounds $\mathbf{3 a}$ and $\mathbf{3 c}$ to produce compounds $\mathbf{3 e}$ and $\mathbf{3 g}$, respectively, resulted in ca. 2.5-4.2 fold decreases in radical scavenging activity. Whereas, complete methylation of $\mathbf{3 b}$ and $\mathbf{3 d}$ (bromine containing analogues) to afford $\mathbf{3 f}$ and $\mathbf{3 h}$, respectively, resulted in $c a$. 5.5-1.6 fold increase in activity as compared with 3b and 3d. The results obtained in the present study led us to speculate that a hydroxyl group at $\mathrm{R}_{2}$ promotes the antioxidant activity of hydroxyl substituted analogues (e.g., 3a>3c). However, an additional $\mathrm{OH}$ group at $\mathrm{R}_{4}\left(\mathrm{R}_{1}=\mathrm{R}_{3}=\mathrm{R}_{4}=\mathrm{OH}\right)$ in $\mathbf{3 i}$ or 3j more potently increased activity.
Table 5. DPPH Radical Scavenging Activities of the Novel 2-Arylidenehydrazinyl-4-arylthiazole Analogues 3a-p

\begin{tabular}{crcc}
\hline \hline Compd. no & $\mathrm{IC}_{50}(\mu \mathrm{M})$ & Compd. no & $\mathrm{IC}_{50}(\mu \mathrm{M})$ \\
\hline $\mathbf{3 a}$ & 0.81 & $\mathbf{3 i}$ & 1.08 \\
$\mathbf{3 b}$ & 14.47 & $\mathbf{3 j}$ & 0.66 \\
$\mathbf{3 c}$ & 1.67 & $\mathbf{3 k}$ & 15.55 \\
$\mathbf{3 d}$ & 15.37 & $\mathbf{3 l}$ & 1.96 \\
$\mathbf{3 e}$ & 1.98 & $\mathbf{3 m}$ & 5.48 \\
$\mathbf{3 f}$ & 2.63 & $\mathbf{3 n}$ & 2.89 \\
$\mathbf{3 g}$ & 6.97 & $\mathbf{3 o}$ & 6.13 \\
$\mathbf{3 h}$ & 9.81 & $\mathbf{3 p}$ & 5.70 \\
Ascorbic acid & & & 0.87 \\
\hline
\end{tabular}

\section{Conclusion}

The present study reports on the synthesis of novel 2-arylidenehydrazinyl-4-arylthiazole analogues and their antibacterial and antioxidant activities. Using Hantzsch's method, 16 compounds were prepared from arylidenethiosemicarbazones and investigated with respect to their inhibitory effects on eleven bacteria and their DPPH free radical scavenging activities. All compounds showed significant bactericidal effects on Gram-positive and Gram-negative bacteria. Of the compounds tested, $\mathbf{3 g}$ produced the largest inhibition zones against $E$. coli and $K$. pneumonia, $3 \mathbf{i}$ against $E$. faecalis, $\mathbf{3 n}$ against $S$. tythi and E. faecalis, and $3 \mathbf{c}$ against $E$. coli and $C$. sakazakii. Compounds $\mathbf{3 a}, \mathbf{3 b}, \mathbf{3 e}, \mathbf{3 f}, \mathbf{3 h}-\mathbf{i}$, and $\mathbf{3 i}-\mathbf{n}$ significantly inhibited the growth of $Y$. pestis, whereas the positive control antibiotic, nalidixic acid, showed no activity. Quantum-chemical and physicochemical calculations indicate that antibacterial activity correlates well with calculated $\log P$, PSA and HOMO-LUMO energy difference of molecules. Furthermore, most of the compounds showed significant DPPH radical scavenging activity, and compounds $\mathbf{3 j}$ and $\mathbf{3 a}$ were found to be more potent than ascorbic acid. In our opinion, QSAR studies with respect to antibacterial and antioxidant effects are likely to aid the development of new therapeutic agents for diseases caused by microorganisms or oxidative stress.

\section{Experimental}

General The melting points of the synthesized compounds were determined using a Stuart SMP3 apparatus, and results are uncorrected. Fourier transform (FT)-IR spectra were obtained using a Bruker Tensor 37 spectrometer using $\mathrm{KBr}$ discs. NMR spectra were recorded using a Bruker $400 \mathrm{MHz}$ spectrometer in $\mathrm{CDCl}_{3}$ using TMS as an internal standard. EI- and FAB-MS spectra were acquired using a Jeol JMS-700 mass spectrometer. Elemental analyses $(\mathrm{C}, \mathrm{H}, \mathrm{N})$ were performed on a PerkineElmer 2400 II CHN elemental analyzer.

General Procedures for the Preparation of Thiosemicarbazone Analogues (2a-j) The thiosemicarbazone analogues were prepared as we previously reported. ${ }^{20)}$ Briefly, to a stirred solution of thiosemicarbazide $(1 \mathrm{mmol})$ in an ethanolwater mixture, an ethanolic solution of a substituted benzaldehyde ( $1 \mathrm{mmol}$ ) was added slowly and refluxed for 10-20 min. After cooling the reaction mixture to ambient temperature, the mixture was filtered to provide a solid crude product, which was crystallized from ethanol to furnish pure compounds $\mathbf{2 a}-\mathbf{j}$ at yields of $83-94 \%$.

2-(3,4-Dihydroxybenzylidine)hydrazinecarbothioamide (2a) 
Yield $83 \%, \mathrm{mp} 237-238^{\circ} \mathrm{C}$ (brown powder). IR ( $\left.\mathrm{cm}^{-1}\right)$ : 3432 $\left(\mathrm{OH}, \mathrm{NH}_{2}\right), 3259(\mathrm{NH}), 1588(\mathrm{C}=\mathrm{N}), 1295(\mathrm{C}=\mathrm{S}) .{ }^{1} \mathrm{H}-\mathrm{NMR}$ (ppm) $\delta: 6.42$ (d, 1H, J=7.2 Hz, Ar-H), 6.85 (s, 1H, Ar-H), 7.04 $(\mathrm{d}, 1 \mathrm{H}, J=7.2 \mathrm{~Hz}, \mathrm{Ar}-\mathrm{H}), 7.85$ and $7.94\left(2 \times \mathrm{s}, 2 \mathrm{H}, \mathrm{NH}_{2}\right), 8.08$ $(\mathrm{s}, 1 \mathrm{H},=\mathrm{CH}), 11.32(\mathrm{~s}, 1 \mathrm{H}, \mathrm{NH})$. EI-MS $m / z(\%): 211\left(\mathrm{M}^{+}\right.$, 25), 209 (100), 193 (30), 175 (20), 136 (18).

2-(2,4-Dihydroxybenzylidine)hydrazinecarbothioamide (2b) Yield $85 \%, \mathrm{mp} 234-235^{\circ} \mathrm{C}$ (yellow powder). IR $\left(\mathrm{cm}^{-1}\right): 3430$ $\left(\mathrm{OH}, \mathrm{NH}_{2}\right), 3261(\mathrm{NH}), 1590(\mathrm{C}=\mathrm{N}), 1299(\mathrm{C}=\mathrm{S}) .{ }^{1} \mathrm{H}-\mathrm{NMR}$ (ppm) $\delta:$ 6.42-6.54 (m, 2H, Ar-H), $7.60(\mathrm{~d}, 1 \mathrm{H}, J=7.2 \mathrm{~Hz}$, Ar-H), 7.76 and $7.92\left(2 \times s, 2 \mathrm{H}, \mathrm{NH}_{2}\right), 8.24(\mathrm{~s}, 1 \mathrm{H},=\mathrm{CH}), 11.28$ (s, 1H, NH). EI-MS m/z (\%): $211\left(\mathrm{M}^{+}, 12\right), 209$ (100), 192 (30), $136(15)$.

2-(3,4-Dimethoxybenzylidine)hydrazinecarbothioamide (2c) Yield $92.8 \%, \mathrm{mp} 206-207^{\circ} \mathrm{C}$ (white powder). IR ( $\left.\mathrm{cm}^{-1}\right): 3405$ $\left(\mathrm{NH}_{2}\right), 3241(\mathrm{NH}), 1590(\mathrm{C}=\mathrm{N}), 1300(\mathrm{C}=\mathrm{S}) .{ }^{1} \mathrm{H}-\mathrm{NMR}(\mathrm{ppm})$ $\delta$ : 3.79 and $3.81\left(2 \times \mathrm{s}, 6 \mathrm{H}, \mathrm{OCH}_{3}\right), 6.96(\mathrm{~d}, 1 \mathrm{H}, J=8.3 \mathrm{~Hz}$, Ar-H), 7.5 (s, 1H, Ar-H), 7.14 (d, 1H, J=8.3 Hz, Ar-H), 7.96 and $8.02\left(2 \times \mathrm{s}, 2 \mathrm{H}, \mathrm{NH}_{2}\right), 8.16(\mathrm{~s}, 1 \mathrm{H},=\mathrm{CH}), 11.40(\mathrm{~s}, 1 \mathrm{H}$, NH). EI-MS m/z (\%): $239\left(\mathrm{M}^{+}, 100\right), 222$ (30), 149 (15), 114 (30).

2-(2,4-Dimethoxybenzylidine)hydrazinecarbothioamide (2d) Yield $94 \%, \mathrm{mp} 198-199^{\circ} \mathrm{C}$ (white crystal). IR $\left(\mathrm{cm}^{-1}\right): 3408$ $\left(\mathrm{NH}_{2}\right), 3270(\mathrm{NH}), 1578(\mathrm{C}=\mathrm{N}), 1299(\mathrm{C}=\mathrm{S}) .{ }^{1} \mathrm{H}-\mathrm{NMR}(\mathrm{ppm})$ $\delta$ : 3.80 and $3.82\left(2 \times \mathrm{s}, 6 \mathrm{H}, \mathrm{OCH}_{3}\right), 6.56-6.69(\mathrm{~m}, 2 \mathrm{H}, \mathrm{Ar}-\mathrm{H})$, $7.20(\mathrm{~s}, 1 \mathrm{H}, \mathrm{Ar}-\mathrm{H}), 8.24(\mathrm{~s}, 1 \mathrm{H},=\mathrm{CH}), 7.84$ and $7.93(2 \times \mathrm{s}, 2 \mathrm{H}$, $\mathrm{NH}_{2}$ ), 7.4 (d, 1H, J=7.8 Hz, Ar-H), 11.42 (s, 1H, NH). EI-MS $m / z$ (\%): $239\left(\mathrm{M}^{+}, 80\right), 222$ (100), 149 (25), 114 (20).

2-(2,4,6-Trihydroxybenzylidine)hydrazinecarbothioamide (2e) Yield $93.6 \%, \mathrm{mp} 239-240^{\circ} \mathrm{C}$ (red powder). IR $\left(\mathrm{cm}^{-1}\right)$ : $3436\left(\mathrm{OH}, \mathrm{NH}_{2}\right), 3263(\mathrm{NH}), 1581(\mathrm{C}=\mathrm{N}), 1289(\mathrm{C}=\mathrm{S})$. ${ }^{1} \mathrm{H}-\mathrm{NMR}(\mathrm{ppm}) \delta: 6.48(\mathrm{~s}, 2 \mathrm{H}, \mathrm{Ar}-\mathrm{H}), 7.86$ and $7.96(2 \times \mathrm{s}, 2 \mathrm{H}$, $\left.\mathrm{NH}_{2}\right), 8.04(\mathrm{~s}, 1 \mathrm{H},=\mathrm{CH}), 11.18(\mathrm{~s}, 1 \mathrm{H}, \mathrm{NH})$. EI-MS $\mathrm{m} / \mathrm{z}(\%)$ : $227\left(\mathrm{M}^{+}, 100\right), 224$ (38), 193 (30), 152 (15), 138 (45).

2-(3-Methoxy-4-hydroxybenzylidine)hydrazinecarbothioamide (2f) Yield $88.6 \%, \mathrm{mp} 194-195^{\circ} \mathrm{C}$ (yellow powder). IR ( $\left.\mathrm{cm}^{-1}\right): 3437\left(\mathrm{OH}, \mathrm{NH}_{2}\right), 3265(\mathrm{NH}), 1596(\mathrm{C}=\mathrm{N}), 1299$ $(\mathrm{C}=\mathrm{S}) .{ }^{1} \mathrm{H}-\mathrm{NMR}(\mathrm{ppm}) \delta: 3.81\left(\mathrm{~s}, 3 \mathrm{H}, \mathrm{OCH}_{3}\right), 6.69(\mathrm{~d}, 1 \mathrm{H}$, $J=7.2 \mathrm{~Hz}, \mathrm{Ar}-\mathrm{H}$ ), 7.06 (d, $1 \mathrm{H}, J=7.2 \mathrm{~Hz}, \mathrm{Ar}-\mathrm{H}$ ), 7.11 (s, $1 \mathrm{H}$, Ar-H), 7.89 and $7.93\left(2 \times s, 2 \mathrm{H}, \mathrm{NH}_{2}\right), 8.08(\mathrm{~s}, 1 \mathrm{H},=\mathrm{CH})$, 11.26 (s, 1H, NH). EI-MS m/z (\%): $225\left(\mathrm{M}^{+}, 100\right), 224$ (30), 165 (30), 150 (20), 136 (65). The spectral data of compounds $\mathbf{2 g - j}$ was described in our previous study. ${ }^{20)}$

General Procedure for the Preparation of 1,3-Thiazole Analogues (3a-p) The novel 1,3-thiazole analogues were prepared by the modification of our previous methods. ${ }^{20)}$ Briefly, a mixture of thiosemicarbazone $(1 \mathrm{mmol})$ and 2-bromoacetophenone or 2,4'-dibromoacetophenone $(1 \mathrm{mmol})$ in ethanol was refluxed for $30-60 \mathrm{~min}$ and then cooled to ambient temperature. The resulting precipitate was filtered and washed with water to give a crude product, which was purified by crystallization in a $N, N$-dimethylformamide (DMF)EtOH mixture, affording pure 1,3-thiazole derivatives at yields of $72-95 \%$.

2-(3,4-Dihydroxybenzylidine)hydrazinyl-4-phenylthiazole (3a) Yield $77 \%, \mathrm{mp} 227-228^{\circ} \mathrm{C}$ (red crystal). IR ( $\mathrm{cm}^{-1}$ ): 3417 $(\mathrm{OH}), 3167(\mathrm{NH})$, 3001, 1625, $1525(\mathrm{C}=\mathrm{C}, \mathrm{C}=\mathrm{N}) .{ }^{1} \mathrm{H}-\mathrm{NMR}$ (ppm) $\delta$ : $7.00-7.36(\mathrm{~m}, 8 \mathrm{H}$, Ar-H+thiazole-H), $7.86(\mathrm{~d}, 1 \mathrm{H}$, $J=7.80 \mathrm{~Hz}, \mathrm{Ar}-\mathrm{H}), 7.93$ (s, $1 \mathrm{H}, \mathrm{CH}=\mathrm{N}), 11.28$ (s, 1H, NH). EI-MS m/z (\%): $311\left(\mathrm{M}^{+}, 5\right), 231$ (28), 216 (20), 176 (100), 134 (75). Anal. Calcd for $\mathrm{C}_{16} \mathrm{H}_{13} \mathrm{~N}_{3} \mathrm{O}_{2} \mathrm{~S}$ : C, 61.72; H, 4.21; N, 13.50 .
Found: C, 61.80; H, 4.29; N, 13.61.

2-(3,4-Dihydroxybenzylidine)hydrazinyl-4-(4-bromophenyl)thiazole (3b) Yield $75 \%, \mathrm{mp} 168-169^{\circ} \mathrm{C}$ (brown powder). IR $\left(\mathrm{cm}^{-1}\right)$ : $3468(\mathrm{OH}), 3185(\mathrm{NH}), 3050,1602,1502(\mathrm{C}=\mathrm{C}, \mathrm{C}=\mathrm{N})$. ${ }^{1} \mathrm{H}-\mathrm{NMR}(\mathrm{ppm}) \delta$ : $7.0(\mathrm{~d}, 1 \mathrm{H}, J=8.2 \mathrm{~Hz}, \mathrm{Ar}-\mathrm{H}), 7.16-7.36(\mathrm{~m}$, 5H, Ar-H+thiazole-H), 7.8 (d, 2H, J=8.78 Hz, Ar-H), 7.97 (s, $1 \mathrm{H}, \mathrm{CH}=\mathrm{N}), 12.01(\mathrm{~s}, 1 \mathrm{H}, \mathrm{NH})$. FAB-MS $m / z(\%): 390\left(\mathrm{M}^{+}\right.$, 5). Anal. Calcd for $\mathrm{C}_{16} \mathrm{H}_{12} \mathrm{BrN}_{3} \mathrm{O}_{2} \mathrm{~S}$ : C, 49.24; H, 3.10; N, 10.77 . Found: C, 49.31; H, 3.19; N, 10.84 .

2-(2,4-Dihydroxybenzylidine)hydrazinyl-4-phenylthiazole (3c) Yield $76.5 \%, \mathrm{mp} 212-213^{\circ} \mathrm{C}$ (straw powder). IR $\left(\mathrm{cm}^{-1}\right)$ : $3400(\mathrm{OH}), 3196(\mathrm{NH}), 3000,1600,1550(\mathrm{C}=\mathrm{C}, \mathrm{C}=\mathrm{N})$. ${ }^{1} \mathrm{H}-\mathrm{NMR}(\mathrm{ppm}) \delta$ : 6.33-6.35 (m, 2H, Ar-H), 7.25-7.42 (m, $5 \mathrm{H}$, Ar-H+thiazole-H), 7.84 (d, 2H, J=7.80 Hz, Ar-H), 8.21 $(\mathrm{s}, 1 \mathrm{H}, \mathrm{CH}=\mathrm{N}), 11.16(\mathrm{~s}, 1 \mathrm{H}, \mathrm{NH}) . \mathrm{EI}-\mathrm{MS} m / z(\%): 311\left(\mathrm{M}^{+}\right.$, 87), 294 (20), 176 (100), 162 (18), 134 (52). Anal. Calcd for $\mathrm{C}_{16} \mathrm{H}_{13} \mathrm{~N}_{3} \mathrm{O}_{2} \mathrm{~S}: \mathrm{C}, 61.72 ; \mathrm{H}, 4.21 ; \mathrm{N}, 13.50$. Found: C, 61.82; H, 4.30; N, 13.59 .

2-(2,4-Dihydroxybenzylidine)hydrazinyl-4-(4-bromophenyl)thiazole (3d) Yield $73 \%, \mathrm{mp} 248-249^{\circ} \mathrm{C}$ (brown powder). IR $\left(\mathrm{cm}^{-1}\right)$ : $3409(\mathrm{OH}), 3150(\mathrm{NH}), 3025,1600,1550(\mathrm{C}=\mathrm{C}, \mathrm{C}=\mathrm{N})$. ${ }^{1} \mathrm{H}-\mathrm{NMR}(\mathrm{ppm}) \delta: 6.33-6.36(\mathrm{~m}, 1 \mathrm{H}, \mathrm{Ar}-\mathrm{H}), 7.34-7.80(\mathrm{~m}, 7 \mathrm{H}$, Ar-H+thiazole-H), $8.21(\mathrm{~s}, 1 \mathrm{H}, \mathrm{CH}=\mathrm{N}), 11.12(\mathrm{~s}, 1 \mathrm{H}, \mathrm{NH})$. EI-MS m/z (\%): $392(\mathrm{M}+3,10), 391(\mathrm{M}+2,53), 390(\mathrm{M}+1,11)$, $389\left(\mathrm{M}^{+}, 52\right), 256$ (100), 254 (98), 214 (22), 212 (23), 174 (62), 137 (29). Anal. Calcd for $\mathrm{C}_{16} \mathrm{H}_{12} \mathrm{BrN}_{3} \mathrm{O}_{2} \mathrm{~S}$ : C, 49.24; H, 3.10; N, 10.77. Found: C, 49.33; H, 3.21; N, 10.86 .

2-(3,4-Dimethoxybenzylidine)hydrazinyl-4-phenylthiazole (3e) Yield $77 \%, \mathrm{mp} 235-236^{\circ} \mathrm{C}$ (white crystal). IR $\left(\mathrm{cm}^{-1}\right)$ : $3233(\mathrm{NH}), 3063,1617,1534(\mathrm{C}=\mathrm{C}, \mathrm{C}=\mathrm{N}) .{ }^{1} \mathrm{H}-\mathrm{NMR}(\mathrm{ppm})$ $\delta: 3.80\left(\mathrm{~s}, 3 \mathrm{H}, \mathrm{OCH}_{3}\right), 3.82\left(\mathrm{~s}, 3 \mathrm{H}, \mathrm{OCH}_{3}\right), 7.01-7.44(\mathrm{~m}, 7 \mathrm{H}$, Ar-H+thiazole-H), 7.85 (d, 2H, $J=1.98 \mathrm{~Hz}, \mathrm{Ar}-\mathrm{H}), 7.98$ (s, 1H, $\mathrm{CH}=\mathrm{N}), 11.28(\mathrm{~s}, 1 \mathrm{H}, \mathrm{NH})$. EI-MS $m / z(\%): 339\left(\mathrm{M}^{+}, 40\right)$, 177 (10), 176 (100), 134 (29). Anal. Calcd for $\mathrm{C}_{18} \mathrm{H}_{17} \mathrm{~N}_{3} \mathrm{O}_{2} \mathrm{~S}$ : C, 63.70; H, 5.05; N, 12.38. Found: C, 63.81; H, 5.12; N, 12.45.

2-(3,4-Dimethoxybenzylidine)hydrazinyl-4-(4-bromophenyl)thiazole (3f) Yield $74 \%, \mathrm{mp} 182-183^{\circ} \mathrm{C}$ (pink powder). IR $\left(\mathrm{cm}^{-1}\right)$ : $3200(\mathrm{NH})$, 3002, 1600, $1517(\mathrm{C}=\mathrm{C}, \mathrm{C}=\mathrm{N}) .{ }^{1} \mathrm{H}-\mathrm{NMR}$ (ppm) $\delta: 3.81\left(\mathrm{~s}, 3 \mathrm{H}, \mathrm{OCH}_{3}\right), 3.79\left(\mathrm{~s}, 3 \mathrm{H}, \mathrm{OCH}_{3}\right), 7.00-7.36$ (m, 4H, +thiazole-H), 7.59 (d, 2H, J=8.00 Hz, Ar-H), 7.80 (d, $2 \mathrm{H}, J=8.00 \mathrm{~Hz}, \mathrm{Ar}-\mathrm{H}), 7.97(\mathrm{~s}, 1 \mathrm{H}, \mathrm{CH}=\mathrm{N}), 12.01$ (s, 1H, NH). EI-MS m/z (\%): $420(\mathrm{M}+3,10), 419(\mathrm{M}+2,39), 418(\mathrm{M}+1,11)$, $417\left(\mathrm{M}^{+}, 38\right), 256$ (100), 254 (98), 174 (36), 97 (58). Anal. Calcd for $\mathrm{C}_{18} \mathrm{H}_{16} \mathrm{BrN}_{3} \mathrm{O}_{2} \mathrm{~S}: \mathrm{C}, 51.68 ; \mathrm{H}, 3.86 ; \mathrm{N}, 10.05$. Found: C, 51.77; $\mathrm{H}, 3.95 ; \mathrm{N}, 10.14$.

2-(2,4-Dimethoxybenzylidine)hydrazinyl-4-phenylthiazole (3g) Yield $75 \%, \mathrm{mp} 219-220^{\circ} \mathrm{C}$ (white crystal). IR $\left(\mathrm{cm}^{-1}\right)$ : $3275(\mathrm{NH}), 3010,1600,1484(\mathrm{C}=\mathrm{C}, \mathrm{C}=\mathrm{N}){ }^{1} \mathrm{H}-\mathrm{NMR}(\mathrm{ppm})$ $\delta$ : $3.80\left(\mathrm{~s}, 3 \mathrm{H}, \mathrm{OCH}_{3}\right), 3.82\left(\mathrm{~s}, 3 \mathrm{H}, \mathrm{OCH}_{3}\right), 6.41-6.70(\mathrm{~m}$, 3H, Ar-H), 7.23-7.72 (m, 3H, Ar-H+thiazole-H), 7.79 (d, 2H, $J=8.78, \mathrm{Ar}-\mathrm{H}), 8.49$ (s, $1 \mathrm{H}, \mathrm{CH}=\mathrm{N}), 11.58$ (s, 1H, NH). EI-MS m/z (\%): $339\left(\mathrm{M}^{+}, 35\right), 176$ (100), 149 (10), 134 (28). Anal. Calcd for $\mathrm{C}_{18} \mathrm{H}_{17} \mathrm{~N}_{3} \mathrm{O}_{2} \mathrm{~S}$ : C, 63.70; H, 5.05; N, 12.38. Found: C, 63.79; H, 5.14; N, 12.47 .

2-(2,4-Dimethoxybenzylidine)hydrazinyl-4-(4-bromophenyl)thiazole (3h) Yield $95 \%, \mathrm{mp} 202-203^{\circ} \mathrm{C}$ (black powder). IR $\left(\mathrm{cm}^{-1}\right): 3276(\mathrm{NH}), 3020,1609,1542(\mathrm{C}=\mathrm{C}, \mathrm{C}=\mathrm{N}){ }^{1} \mathrm{H}-\mathrm{NMR}$ (ppm) $\delta: 3.81\left(\mathrm{~s}, 3 \mathrm{H}, \mathrm{OCH}_{3}\right), 3.85\left(\mathrm{~s}, 3 \mathrm{H}, \mathrm{OCH}_{3}\right), 6.61-6.63$ (m, 1H, Ar-H), 7.33-7.71 (m, 4H, Ar-H+thiazole-H), 7.80 (d, $2 \mathrm{H}, J=7.82 \mathrm{~Hz}, \mathrm{Ar}-\mathrm{H}), 8.26$ (s, $1 \mathrm{H}, \mathrm{CH}=\mathrm{N}), 11.78$ (s, 1H, NH). EI-MS $m / z(\%): 420(\mathrm{M}+3,10), 419(\mathrm{M}+2,33), 418(\mathrm{M}+1$, 
10), 417 (M+, 32), 256 (100), 254 (98), 174 (20), 149 (20). Anal. Calcd for: $\mathrm{C}_{18} \mathrm{H}_{16} \mathrm{BrN}_{3} \mathrm{O}_{2} \mathrm{~S}$ : C, 51.68; H, 3.86; N, 10.05. Found: C, 51.79; H, 3.94; N, 10.12 .

2-(2,4,6-Trihydroxybenzylidine)hydrazinyl-4-phenylthiazole (3i) Yield $74 \%, \mathrm{mp} 224-225^{\circ} \mathrm{C}$ (red powder). IR ( $\mathrm{cm}^{-1}$ ): 3450 (OH), $3159(\mathrm{NH}), 3073,1600,1550(\mathrm{C}=\mathrm{C}, \mathrm{C}=\mathrm{N}) .{ }^{1} \mathrm{H}-\mathrm{NMR}$ (ppm) $\delta$ : 5.98 (s, 2H, Ar-H), 7.28-7.43 (m, 4H, Ar-H+thiazoleH), 7.84 (d, 2H, J=7.80 Hz, Ar-H), $8.46(\mathrm{~s}, 1 \mathrm{H}, \mathrm{CH}=\mathrm{N}), 10.40$ (s, 1H, NH). EI-MS m/z (\%): 327 (M+, 24), 309 (23), 189 (35), 176 (100), 134 (60). Anal. Calcd for $\mathrm{C}_{16} \mathrm{H}_{13} \mathrm{~N}_{3} \mathrm{O}_{3} \mathrm{~S}$ : C, 58.70; H, 4.00; N, 12.84. Found: C, 58.82; H, 4.11; N, 12.91.

2-(2,4,6-Trihydroxybenzylidine)hydrazinyl-4-(4-bromophenyl)thiazole $(\mathbf{3 j}) \quad$ Yield $73 \%, \mathrm{mp} 214-215^{\circ} \mathrm{C}$ (red powder). IR $\left(\mathrm{cm}^{-1}\right): 3467(\mathrm{OH}), 3250(\mathrm{NH}), 3013,1642,1642,1509$ $(\mathrm{C}=\mathrm{C}, \mathrm{C}=\mathrm{N}) .{ }^{1} \mathrm{H}-\mathrm{NMR}(\mathrm{ppm}) \delta: 5.96(\mathrm{~s}, 2 \mathrm{H}, \mathrm{Ar}-\mathrm{H}), 7.36-7.80$ $(\mathrm{m}, 5 \mathrm{H}$, Ar-H+thiazole-H), $8.46(\mathrm{~s}, 1 \mathrm{H}, \mathrm{CH}=\mathrm{N}), 11.39$ (s, 1H, NH). EI-MS m/z (\%): $408(\mathrm{M}+3,6), 407(\mathrm{M}+2,16), 406$ $(\mathrm{M}+1,6), 405\left(\mathrm{M}^{+}, 15\right), 389$ (100), 387 (97), 256 (98), 254 (99), 174 (86), 133 (30). Anal. Calcd for $\mathrm{C}_{16} \mathrm{H}_{12} \mathrm{BrN}_{3} \mathrm{O}_{3} \mathrm{~S}: \mathrm{C}$, 47.30; H, 2.98; N, 10.34. Found: C, 47.42; H, 3.06; N, 10.43.

2-(3-Methoxy-4-hydroxybenzylidine)hydrazinyl-4-phenylthiazole (3k) Yield $74 \%$, mp $235-236^{\circ} \mathrm{C}$ (black powder). IR $\left(\mathrm{cm}^{-1}\right)$ : $3425(\mathrm{OH}), 3167(\mathrm{NH}), 3030,1634,1509(\mathrm{C}=\mathrm{C}, \mathrm{C}=\mathrm{N})$. ${ }^{1} \mathrm{H}-\mathrm{NMR}(\mathrm{ppm}) \delta: 3.82\left(\mathrm{~s}, 3 \mathrm{H}, \mathrm{OCH}_{3}\right), 6.82(\mathrm{~d}, 1 \mathrm{H}, J=7.80 \mathrm{~Hz}$, Ar-H), 7.01-7.43 (m, 7H, Ar-H+thiazole-H), 7.84 (d, 1H, $J=7.80 \mathrm{~Hz}, \mathrm{Ar}-\mathrm{H}), 7.95$ (s, $1 \mathrm{H}, \mathrm{CH}=\mathrm{N}), 11.93$ (s, 1H, -NH). EI-MS m/z (\%): $325\left(\mathrm{M}^{+}, 35\right), 231$ (43), 216 (35), 176 (100), 134 (83). Anal. Calcd for $\mathrm{C}_{17} \mathrm{H}_{15} \mathrm{~N}_{3} \mathrm{O}_{2} \mathrm{~S}: \mathrm{C}, 62.75 ; \mathrm{H}, 4.65 ; \mathrm{N}, 12.91$. Found: C, 62.86; H, 4.72; N, 13.01.

2-(3-Methoxy-4-hydroxybenzylidine)hydrazinyl-4-(4-bromophenyl)thiazole (3I) Yield $72 \%, \mathrm{mp} \quad 100-101^{\circ} \mathrm{C}$ (red crystal). IR (cm $\left.{ }^{-1}\right): 3442(\mathrm{OH}), 3200(\mathrm{NH}), 3070,1634,1500$ $(\mathrm{C}=\mathrm{C}, \mathrm{C}=\mathrm{N}) .{ }^{1} \mathrm{H}-\mathrm{NMR}(\mathrm{ppm}) \delta: 3.82\left(\mathrm{~s}, 3 \mathrm{H}, \mathrm{OCH}_{3}\right), 6.82(\mathrm{~d}$, $1 \mathrm{H}, J=7.80 \mathrm{~Hz}, \mathrm{Ar}-\mathrm{H}), 7.06-7.35$ (m, 3H, Ar-H+thiazole-H), 7.59 (d, 2H, $J=7.80 \mathrm{~Hz}$, Ar-H), 7.80 (d, 2H, $J=7.80 \mathrm{~Hz}$, Ar-H), $7.93(\mathrm{~s}, 1 \mathrm{H}, \mathrm{CH}=\mathrm{N}), 9.39(\mathrm{~s}, 1 \mathrm{H}, \mathrm{OH}), 11.93(\mathrm{~s}, 1 \mathrm{H}, \mathrm{NH})$. EI-MS $m / z(\%): 406(\mathrm{M}+3,10), 405(\mathrm{M}+2,40), 404(\mathrm{M}+1$, 10), 403 ( $\left.\mathrm{M}^{+}, 40\right), 256$ (100), 254 (99), 174 (34), 134 (10). Anal. Calcd for $\mathrm{C}_{17} \mathrm{H}_{14} \mathrm{BrN}_{3} \mathrm{O}_{2} \mathrm{~S}$ : C, 50.50; H, 3.49; N, 10.39. Found: C, $50.62 ; \mathrm{H}, 3.56 ; \mathrm{N}, 10.48$.

2-(4-Hydroxybenzylidine)hydrazinyl-4-(4-bromophenyl)thiazole (3m) Yield $74 \%$, mp $232-233^{\circ} \mathrm{C}$ (brown powder). IR $\left(\mathrm{cm}^{-1}\right): 3475(\mathrm{OH}), 3175(\mathrm{NH}), 3063,1617,1513(\mathrm{C}=\mathrm{C}, \mathrm{C}=\mathrm{N})$ ${ }^{1} \mathrm{H}-\mathrm{NMR}(\mathrm{ppm}) \delta: 6.81$ (d, 2H, $\left.J=8.2 \mathrm{~Hz}, \mathrm{Ar}-\mathrm{H}\right), 7.35-7.59$ (s, 5H, Ar-H+thiazole-H), 7.79 (d, 2H, J=8.2 Hz, Ar-H), 7.94 (s, $1 \mathrm{H}, \mathrm{CH}=\mathrm{N}), 9.81(\mathrm{~s}, 1 \mathrm{H}, \mathrm{OH}), 11.90$ (s, 1H, NH). EI-MS m/z (\%): $376(\mathrm{M}+3,11), 375(\mathrm{M}+2,45), 374(\mathrm{M}+1,12), 373\left(\mathrm{M}^{+}\right.$, 44), 256 (100), 254 (100), 174 (52), 133 (10). Anal. Calcd for $\mathrm{C}_{16} \mathrm{H}_{13} \mathrm{~N}_{3} \mathrm{OS}: \mathrm{C}, 65.06 ; \mathrm{H}, 4.44 ; \mathrm{N}, 14.23$. Found: C, 65.17; H, 4.52; N, 14.33 .

2-(2-Hydroxybenzylidine)hydrazinyl-4-(4-bromophenyl)thiazole (3n) Yield $84 \% \mathrm{mp} 243-244^{\circ} \mathrm{C}$ (yellow crystal). IR $\left(\mathrm{cm}^{-1}\right)$ : $3442(\mathrm{OH}), 3175(\mathrm{NH}), 3065,1617,1492(\mathrm{C}=\mathrm{C}, \mathrm{C}=\mathrm{N})$. ${ }^{1} \mathrm{H}-\mathrm{NMR}(\mathrm{ppm}) \delta$ : 6.8-6.9 (m, 2H, Ar-H), 7.21-7.63 (m, 5H, Ar-H+thiazole-H), 7.80 (d, 2H, $J=8.00 \mathrm{~Hz}$, Ar-H), $8.32(\mathrm{~s}, 1 \mathrm{H}$, $\mathrm{CH}=\mathrm{N}), 10.06$ (s, 1H, OH), $12.11(\mathrm{~s}, 1 \mathrm{H}, \mathrm{NH})$. EI-MS m/z (\%): $376(\mathrm{M}+3,19), 375(\mathrm{M}+2,86), 374(\mathrm{M}+1,20), 373\left(\mathrm{M}^{+}, 84\right)$, 256 (100), 254 (97), 174 (60), 147 (15), 133 (14). Anal. Calcd for $\mathrm{C}_{16} \mathrm{H}_{12} \mathrm{BrN}_{3} \mathrm{OS}$ : C, 51.35; $\mathrm{H}, 3.23 ; \mathrm{N}, 11.23$. Found: $\mathrm{C}$, 51.45; H, 3.31; N, 11.34.

2-(4-Chlorobenzylidine)hydrazinyl-4-(4-bromophenyl)thia- zole (3o) Yield $76 \%, \mathrm{mp} \quad 217-218^{\circ} \mathrm{C}$ (gray powder). IR $\left(\mathrm{cm}^{-1}\right): 3174(\mathrm{NH}), 3025,1600,1550(\mathrm{C}=\mathrm{C}, \mathrm{C}=\mathrm{N}) .{ }^{1} \mathrm{H}-\mathrm{NMR}$ (ppm) $\delta$ : 7.41-7.69 (m, 7H, Ar-H+thiazole-H), $7.81(\mathrm{~d}, 2 \mathrm{H}$, $J=7.60 \mathrm{~Hz}, \mathrm{Ar}-\mathrm{H}), 8.03$ (s, $1 \mathrm{H}, \mathrm{CH}=\mathrm{N}), 12.23$ (s, 1H, NH). EI-MS m/z (\%): $394(\mathrm{M}+3,12), 393(\mathrm{M}+2,57), 392(\mathrm{M}+1$, 11), $391\left(\mathrm{M}^{+}, 43\right), 256$ (100), 254 (99), 174 (91). Anal. Calcd for $\mathrm{C}_{16} \mathrm{H}_{11} \mathrm{BrClN}_{3} \mathrm{~S}$ : C, 48.94; H, 2.82; N, 10.70. Found: C, 49.06; $\mathrm{H}, 2.91 ; \mathrm{N}, 10.81$.

2-(4-Dimethylaminobenzylidine)hydrazinyl-4-(4-bromophenyl)thiazole (3p) Yield $83 \%, \mathrm{mp} 230-231^{\circ} \mathrm{C}$ (greenish gray powder). IR $\left(\mathrm{cm}^{-1}\right): 3184(\mathrm{NH}), 3018,1358,1609,1558$ $(\mathrm{C}=\mathrm{C}, \mathrm{C}=\mathrm{N}) .{ }^{1} \mathrm{H}-\mathrm{NMR}(\mathrm{ppm}) \delta: 2.97\left(\mathrm{~s}, 6 \mathrm{H}, \mathrm{N}\left(\mathrm{CH}_{3}\right)_{2}, 6.74\right.$ (m, 2H, Ar-H), 7.32-7.60 (m, 5H, Ar-H+thiazole-H), $7.80(\mathrm{~m}$, 2H, Ar-H), 7.92 (s, 1H, CH=N), 11.80 (s, 1H, NH). EI-MS m/z (\%): $403(\mathrm{M}+3,11), 402(\mathrm{M}+2,46), 401(\mathrm{M}+1,10), 400\left(\mathrm{M}^{+}\right.$, 45), 256 (100), 254 (98), 174 (14), 147 (34). Anal. Calcd for $\mathrm{C}_{18} \mathrm{H}_{17} \mathrm{BrN}_{4} \mathrm{~S}$ : C, 53.87; H, 4.27; N, 13.96. Found: C, 53.98; H, 4.36; N, 14.03 .

Antibacterial Screening A previously described filter paper disc diffusion method ${ }^{20)}$ against all eleven strains was used to determine the in vitro antibacterial effects of all compounds. Briefly, nutrient agar (NA) media (Difco Laboratories, Lawrence, KS, U.S.A.) was used as a basal medium for test bacteria. These agar media were inoculated with $0.2 \mathrm{~mL}$ of 24-h liquid cultures containing the microorganisms. The sample discs were placed gently on pre-inoculated agar plates and then incubated aerobically at $37^{\circ} \mathrm{C}$ for $24 \mathrm{~h}$. Discs with only dimethyl sulfoxide (DMSO) were used as a control, and nalidixic acid was used as a positive control. Inhibitory activity was assessed (in $\mathrm{mm}$ ) by measuring the diameters of observed inhibition zones. These evaluations were performed in triplicate for each compound at a concentration of $300 \mu \mathrm{g} \mathrm{disc}{ }^{-1}$. The minimal inhibitory concentration (MIC, in $\mu \mathrm{g} \mathrm{mL}^{-1}$ ) of selected compounds was determined against, Listeria monocytogenes (ATCC 43256), Enterococcus faecalis (CARS 2011-012), Bacillus subtilis (IFO 13719), Klebsilla pneumonia (JCM 1662), Cronobacter sakazakii (CARS 2012-J-F), Salmonella enteritidis (ATCC 13076), E. coli (CARS 2011-016) and Yersinia pestis (CARS 2013-027) using nutrient broth medium (DIFCO) and a serial dilution technique. ${ }^{25)}$ MIC was defined as the lowest concentration of the tested compound (in DMSO) that inhibited bacterial growth.

DPPH Radical Scavenging Activity The free radicalscavenging activities of the synthesized compounds were assayed according to the Blois method with some modification ${ }^{26}$ ) using DPPH radical. Briefly, to $0.1 \mathrm{~mL}$ samples of different concentrations ( 2.5 to $20 \mathrm{mg} / \mathrm{mL})$ in ethanol, $4 \mathrm{~mL}$ of $1.5 \times 10^{-5} \mathrm{M}$ DPPH solution was added, thoroughly mixed, and then left to stand at room temperature in a dark place. After $30 \mathrm{~min}$ of incubation, solution absorbances were measured at $520 \mathrm{~nm}$ and the activity was calculated using the following equation:

$$
\begin{aligned}
& \text { DPPH radical-scavenging activity }(\%) \\
& =[(\text { Absorbance of the control } \\
& \quad \times \text { Absorbance of the sample }) \\
& \quad \div(\text { Absorbance of the control })] \times 100
\end{aligned}
$$

Computational Studies The molecular geometries of the thiazole analogues were built with a standard bond length and angles using ChemBio3D Pro 12 molecular modeling pro- 
gram (Cambridge Soft Corporation, Cambridge, MA, U.S.A.). The energy was minimized by semi-empirical molecular orbital PM3 method ${ }^{27)}$ and then by the Hartree-Fock method at 6-31G basis set with R-Closed-Shell wave function using GAMESS Interface in the ChemBio3D ultra Ver. 12. Muliken charges and properties of frontier molecular orbitals of the compounds were analyzed using the results calculated at RHF/6-31G level. Physicochemical properties were calculated using molinspiration cheminformatics software (Molinspiration Cheminformatics, SK 90026 Slovensky Grob, SR). The method for calculation of $\operatorname{cog} P$ was developed by Molinspiration (milog $P$ 2.2-2005) based on group contributions and correction factors by fitting calculated $\log P$ with experimental $\log P$ for a training set more than twelve thousand, mostly drug-like molecules. Molecular polar surface area (PSA) was calculated based on the methodology published by Ertl et $a l .{ }^{28)}$ as a sum of fragment contributions. The maps of molecular lipophilicity potential (MLP) and PSA were viewed in Molinspiration Galaxy 3D Structure Generator (ver. 2013.02 beta).

Acknowledgments This work was supported by the Dongguk University at Gyeongju, Korea. Dr. Seen Ae Chae at Korea Basic Science Institute (Daegu) is acknowledged for the NMR data.

\section{References}

1) Vicini P., Geronikaki A., Anastasia K., Incerti M., Zani F., Bioorg. Med. Chem., 14, 3859-3864 (2006).

2) Tenover F. C., McDonald L. C., Curr. Opin. Infect. Dis., 18, 300305 (2005).

3) Ostrosky-Zeichner L., Casadevall A., Galgaini J. N., Odds F. C., Rex J. H., Nat. Rev. Drug Discov., 9, 719-727 (2010).

4) Kathiravan M. K., Salake A. B., Chothe A. S., Dudhe P. B., Watode R. P., Mukta M. S., Gadhwe S., Bioorg. Med. Chem., 20, 5678-5698 (2012).

5) Sun-Waterhouse D., Chen J., Chuah C., Wibisono R., Melton L. D., Laing W., Ferguson L. R., Skinner M. A., Int. J. Food Sci. Nutr., 60 (Suppl 7), 251-264 (2009).

6) Gürsoy E., Güzeldemirci N. U., Eur. J. Med. Chem., 42, 320-326 (2007).

7) Rostom S. A. F., El-Ashmawy I. M., Abd El-Razik H. A., Badr M.
H., Ashour H. M. A., Bioorg. Med. Chem., 17, 882-895 (2009).

8) Bharti S. K., Nath G., Tilak R., Singh S. K., Eur. J. Med. Chem., 45, 651-660 (2010).

9) Ryu C. K., Nho J. H., Jin G., Oh S. Y., Choi S. J., Chem. Pharm. Bull., 62, 668-674 (2014).

10) Shih M. H., Ke K. F., Bioorg. Med. Chem., 12, $4633-4643$ (2004).

11) Zhang W. T., Ruan J. L., Wu P. F., Jiang F. C., Zhang L. N., Fang W., Chen X. L., Wang Y., Cao B. S., Chen G. Y., Zhu Y. J., Gu J., Chen J. G., J. Med. Chem., 52, 718-725 (2009).

12) Iino T., Hashimoto N., Sasaki K., Ohyama S., Yoshimoto R., Hosaka H., Hasegawa T., Chiba M., Nagata Y., EiKi J., Nishimura T., Bioorg. Med. Chem., 17, 3800-3809 (2009).

13) Dash J., Melillo B., Arseniyadis S., Cossy J., Tetrahedron Lett., 52, 2246-2249 (2011).

14) Shiradkar M. R., Akula K. C., Dasari V., Baru V., Chiningiri B., Gandhi S., Kaur R., Bioorg. Med. Chem., 15, 2601-2610 (2007).

15) Chimenti F., Maccioni E., Secci D., Bolasco A., Chimenti P., Granese A., Befani O., Turini P., Alcaro S., Ortuso F., Cardia M. C., Distinto S., J. Med. Chem., 50, 707-712 (2007).

16) Clark R. F., Zhang T., Wang X., Wang R., Zhang X., Camp H. S., Beutel B. A., Sham H. L., Gu Y. J., Bioorg. Med. Chem. Lett., 17, 1961-1965 (2007).

17) Netalkar P. P., Netalkar S. P., Budagumpi S., Revankar V. K., Eur. J. Med. Chem., 79, 47-56 (2014).

18) Turan-Zitouni G., Özdemir A., Kaplancikli Z. A., Phosphorus Sulphur Silicon Relat. Elem., 186, 233-239 (2011).

19) Chimenti F., Secci D., Bolasco A., Chimenti P., Granese A., Carradori S., Yáñez M., Orallo F., Sanna M. L., Gallinella B., Cirilli R., J. Med. Chem., 53, 6516-6520 (2010).

20) Alam M. S., Liu L., Lee Y. E., Lee D. U., Chem. Pharm. Bull., 59, 568-573 (2011).

21) Hantzsch A., Weber H. J., Ber. Dtsch. Chem. Ges., 20, 3118-3132 (1887).

22) Testa B., Carrupt P. A., Gaillard P., Billois F., Weber P., Pharm. Res., 13, 335-343 (1996).

23) Alam M. S., Nam Y. J., Lee D. U., Eur. J. Med. Chem., 69, 790-797 (2013).

24) Cubini H., " Burger's medicinal chemistry and drug discovery," Vol. I, Interscience, New York, 1995.

25) Nishino C., Enoki N., Tawata S., Mori A., Kobayashi K., Fukushima M., Agric. Biol. Chem., 51, 139-143 (1987).

26) Blois M. S., Nature (London), 181, 1199-1200 (1958).

27) Stewart J. J. P., J. Mol. Model., 10, 155-164 (2004).

28) Ertl P., Rohde B., Selzer P., J. Med. Chem., 43, 3714-3717 (2000). 